\title{
Revision of the Frasnian Late Devonian conodont genus Ancyrodella
}

\author{
GILBERT KLAPPER
}

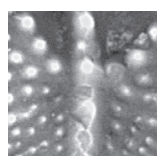

\begin{abstract}
This paper revises all the species of the Frasnian Late Devonian genus Ancyrodella. Seventeen species are recognized, as well as several intraspecific morphotypes not considered separate species. Illustrated specimens are all from collections from the Canning Basin, Western Australia, but publications of global Devonian tropical localities are also reviewed in the synonymies. The taxonomic approach herein is one using the controversial "vertical chronospecies" based primarily on the Pa elements' platform outline and the pattern of secondary carinae and keels, if present. Multielement reconstructions have been few. In view of the widespread confusion and variable application of species names, zonations based on the succession of Ancyrodella species appear premature. $\bullet$ Key words: conodonts, Frasnian Stage, Late Devonian, Canning Basin, Western Australia.
\end{abstract}

KLAPPER, G. 2021. Revision of the Late Devonian conodont genus Ancyrodella. Bulletin of Geosciences 96(3), 295-325 (3 figures, appendix). Czech Geological Survey, Prague. ISSN 1214-1119. Manuscript received February 27, 2021; accepted in revised form June 3, 2021; published online July 4, 2021; issued July 4, 2021.

Gilbert Klapper, Earth and Planetary Sciences, Northwestern University, Evanston, IL 60208, USA; g-klapper@ northwestern.edu

The Frasnian conodont Ancyrodella has not had a comprehensive taxonomic treatment at the genus level for many years, not since two papers by García-López (1986, $1987)$ in which she presented a phylogeny for the entire genus, as did Ziegler (1962a) at a much earlier stage of knowledge. Other papers since the 1980s have dealt only with some of the species of Ancyrodella, whether for taxonomic or biostratigraphic purposes. This is in contrast to three other Frasnian genera, Palmatolepis (e.g., Ziegler 1962a, b; Helms 1963; Ziegler \& Sandberg 1990; Klapper \& Foster 1993; Dzik 2002; Klapper 2007a, b), Ancyrognathus (e.g., Klapper 1990, Sandberg et al. 1992) and Polygnathus (e.g., Ziegler et al. 2000, Ovnatanova \& Kononova 2001). Thus, a taxonomic revision of all Ancyrodella species is overdue.

The purpose of this paper is entirely taxonomic; the biostratigraphy of Ancyrodella has been treated in many papers. The chronostratigraphic definition and GSSP for the lower boundary of the Frasnian Stage is positioned on what was then thought to be the lowest occurrence of A. rotundiloba early form (Klapper et al. 1993; Becker et al. 2012, fig. $22.7=$ A. pristina in current terminology). At the stratotype section, Col du Puech de la Suque in the Montagne Noire, however, Liao et al. (2019) reported a lower occurrence of $A$. pristina approximately $30 \mathrm{~cm}$ below the current GSSP. Of course, it would be possible to lower the GSSP this small stratigraphic interval at the stratotype section. Before this lower occurrence of A. pristina was known, however, another possibility of revision for the GSSP was suggested by Racki \& Wrzolek (1989, p. 233, fig. 1) and Klapper (2000, p. 154). This was to revise the position of the base of the Frasnian to coincide with the lowest occurrence $A$. rotundiloba s.s. (= late form in earlier terminology), because that is part of a lineage, whereas A. pristina enters known sections as a cryptogene.

\section{A Taxonomic controversy}

Dzik (1985, pp. 72-74; 1990, fig. 4) advocated horizontally defined chronospecies (that is, use of a population approach), both for ammonoids and conodonts, as opposed to vertically defined chronospecies in his terminology. The latter he terms "typologic", which implies basing fossil species on a highly limited sample of specimens. It can be said, however, that some practitioners of the vertical concept can and have also analyzed large samples from fossil populations. A fundamental issue is whether or not the vertical as well as the horizontal approach to species definition demonstrates the full range of intraspecific variation, a feature that has often been ignored in much recent conodont literature (Klapper \& Vodrážková 2013).

Dzik (2002, e.g., fig. 49; Dzik et al. 2018, fig. 10) used a zonation for the Frasnian based on the succession of species of Ancyrodella that "seems much more reliable as the basis for time correlation than the evolution of palmatolepidids [Palmatolepis and Mesotaxis], widely used for this purpose" (op. cit. 2002, p. 621). He recom- 
mended such a zonation despite stating the caveat that "Ancyrodella species are generally very variable and the status of the majority of them is questionable" (op. cit., p. 618). If this is correct, then how can a zonation based on species of Ancyrodella be practicable? In an attempt to answer this question, the synonymies in the Systematic Paleontology section herein indicate that many of the species have been deeply conflated. Recently, Pisarzowska et al. (2020) used a Frasnian zonation based on Ancyrodella species that is subject to the same reservations as Dzik's zonation.

Dzik (2002, p. 617) criticized a number of authors of papers involving Ancyrodella (from Klapper 1985 to Gouwy \& Bultynck 2000, seven papers in all) for using "the vertical (typological) species concept which is highly inappropriate for such a variable and ontogenetically sensitive character as these conodonts' platform shape".

Nevertheless, is Dzik's use of a horizontal species concept superior in practice to a vertical approach, which it is according to his theoretical viewpoint? In Dzik et al. (2018, fig. 3) Ancyrodella nodosa, the defining species of its eponymous zone, is illustrated by five specimens. Leaving aside the juvenile specimen (Dzik et al. 2018, fig. $3 \mathrm{k}$ ) and a fragmentary and poorly preserved specimen from one of the two Vietnam sections of the 2018 paper (fig. 3o), the three Polish specimens represent two distinct species in the vertical taxonomic approach used herein (fig. $31, \mathrm{~m}=A$. nodosa and $3 \mathrm{n}=A$. lobata). The specimens in fig. 31-n are from the same Holy Cross Mts section and sample but Dzik has not in either paper shown intermediates between the two "vertical" species, the differences of which are outlined in the Systematic Paleontology section. Dzik (2002, fig. 26) used biometrics, involving platform element length and density of tubercles, on earlier species of Ancyrodella, but did not publish biometrics supporting his horizontal concept of $A$. nodosa. Platform shape of the Pa (P1) element, which Dzik (op. cit., p. 617) discounted as too variable, is in contrast heavily weighted in the taxonomic approach used herein.

This paper attempts to analyze all species of Ancyrodella here considered valid, by means of comparisons and nearly complete synonymies. Specimens illustrated in the literature that are not well enough preserved or not provided with critical lower views, when such are needed, are not listed in the synonymies in most instances. Unfortunately, not all the valid species could be illustrated from the available Canning Basin material at this time, but all are represented in the published literature.

\section{Systematic paleontology}

This analysis focuses on the Pa element of Ancyrodella (in the system of notation used by Sweet 1988 and his earlier papers). The diagnoses are limited to the distinguishing morphologic characteristics of the species. Multielement reconstructions have been few, primarily that of Schülke (1997); two other partial reconstructions are cited in the synonymies. The photographs on Figure 1B-R and all of Figure 3A-I were taken with a Canon D50 digital camera mounted on a Leitz Aristophot with a $50 \mathrm{~mm}$ Milar lens. Figure 1A and Figure 2A-K were taken with the same Aristophot and lens but with a Leica M back and Kodak Technical Pan film. All specimens on Figures 1-3 are from the Canning Basin and are reposited in the Geological Survey of Western Australia (GSWA) collections with numbers following the letter F. As a matter of presentation only, the genus is divided into four groups.

\section{Genus Ancyrodella Ulrich \& Bassler, 1926}

Type Species. - Ancyrodella nodosa Ulrich \& Bassler, 1926.

\section{Ancyrodella rotundiloba Group}

The group includes $A$. binodosa, $A$. crosbiensis, $A$. pristina, A. recta, A. rotundiloba s.s., A. rugosa, and A. triangulata.

\section{Ancyrodella binodosa Uyeno, 1967}

1967 Ancyrodella rotundiloba binodosa n. subsp.; Uyeno, pp. 4, 5, pl. 1, figs 2, 4, 5 [fig. 2 = holotype].

[non] 1970 Ancyrodella prima sp. nov.; Khalymbadzha \& Chernysheva, pp. 88, 89, pl. 1, figs 1, 2 [= transitional between $A$. binodosa and $A$. pristina].

1973 Ancyrodella rotundiloba binodosa Uyeno. - Ziegler, pp. 35, 36, Ancyro pl. 1, fig. 4 [reillustration of holotype].

1974 Ancyrodella rotundiloba binodosa Uyeno. - Uyeno, pp. 24, 25, pl. 1, figs 4-6 [fig. $5=$ reillustration of Uyeno 1967, pl. 1, fig. 4; non fig. 2 = A. pristina]; pl. 2, figs 2, 3, 5 [fig. 2 = reillustration of holotype; fig. 3 = Uyeno 1967, pl. 1, fig. 5].

[non] 1981 Ancyrodella binodosa Uyeno. - Bultynck \& Hollard, p. 38, pl. 10, fig. 4 [= transitional between $A$. binodosa and $A$. pristina].

1982 Ancyrodella binodosa Uyeno. - Bultynck, p. 56, pl. 1, figs 18, 25, 28-30 [only].

1982 Ancyrodella binodosa Uyeno. - Mouravieff, pp. 112, 113, pl. 1, figs 1-3, 9, 11, 13, 21 [only; fig. 8 ? = juvenile]; pl. 2, figs 2, 3 .

1983 Ancyrodella binodosa Uyeno delta morphotype. Bultynck, p. 165, figs 1.12-1.15 [non figs 1.16-1.20= transitional between $A$. binodosa and $A$. pristina].

1986 Ancyrodella binodosa Uyeno. - García-López, p. 450, pl. 1, figs 1-3 [non figs $4,5=$ ?]. 
1987 Ancyrodella binodosa Uyeno. - García-López, pp. 58, 59, pl. 1, figs 1-3 [non figs 4, $5=$ ?; same illustrations as preceding reference].

1989 Ancyrodella binodosa Uyeno. - Sandberg, Ziegler \& Bultynck, pp. 209, 210, fig. 2.1, pl. 1, figs 1, 2.

1991 Ancyrodella sp. aff. A. binodosa Uyeno. - Irwin \& Orchard, p. 206, pl. 2, fig. 2.

1993 Ancyrodella binodosa Uyeno. - Racki \& Bultynck, pl. 7, figs 7, 8 .

1999 Ancyrodella binodosa Uyeno. - Lazreq, pp. 57, 58, pl. 3, figs 4-7.

2007 Ancyrodella binodosa Uyeno. - Gouwy, Haydukiewicz \& Bultynck, p. 388.

2013 Ancyrodella binodosa Uyeno. - Gouwy, Liao \& Valenzuela-Ríos, pp. 322, 323, fig. 6d-g.

2013 Ancyrodella binodosa Uyeno. - Gholamalian et al., p. 143, pl. 1, figs 14-19.

2017 Ancyrodella binodosa Uyeno. - Ovnatanova et al., p. 1045,1046 , pl. 8 , fig. 8 .

Diagnosis. - Ancyrodella binodosa is restricted to specimens with a single large node on each anterior lobe, but extends to rarer forms with 1-2 tiny posterior denticles.

Remarks. - Ancyrodella binodosa characteristically has only a single large node on each circular anterior lobe (e.g., Uyeno, 1974, pl. 2, fig. 5; Bultynck, 1982, pl. 1, figs $25,28-30)$. Exceptional forms have at most 1-2 small denticles posterior of the anterior large nodes (e.g., Uyeno 1967, pl. 1, fig. 4b). The species should be restricted to these forms. The delta morphotype of $A$. binodosa sensu Bultynck \& Jacobs (1981, pl. 9, figs 3, 4, 7, 8) has more posterior nodes, except the juvenile in fig. 5 , and is considered herein as transitional between $A$. binodosa and $A$. pristina (see synonymy for the latter). This restricted concept of $A$. binodosa is in agreement with the discussion and species definition of Gouwy et al. (2007, p. 388).

Juveniles of $A$. binodosa are difficult to distinguish from those of later Ancyrodella species such as A. pristina and $A$. rotundiloba s.s., if taken out of stratigraphic context. Therefore, confident identification should be based on large, adult specimens as emphasized by Gouwy et al. (2007, op. cit.).

There are transitional specimens between $A$. binodosa and $A$. pristina, as indicated in their synonymy lists, including the $A$. prima holotype. These are not assigned to either species.

"Occurring with Ancyrodella binodosa in sample 'F 27 top' at Blauer Bruch, near Bad Wildungen, Germany, a locality notable for the abundant sequential occurrence of species of Ancyrodella, is a small specimen identified as Ancyrodella sp. (Sandberg et al. 1989, pl. 1, figs 7, 8 and text-fig. 4). This specimen, which displays two pointed conical denticles protruding laterally from the blade, is now considered to represent another early species of Ancyrodella rather than an unidentifiable juvenile" (C.A. Sandberg, written communication, February 24, 2021).

\section{Ancyrodella crosbiensis Kralick, 1994}

1981 Polygnathus cristatus Hinde. - Huddle, pp. b28, b29, pl. 9, figs 11-19; pl. 10, figs 1-18.

1994 Ancyrodella crosbiensis n. sp.; Kralick, p. 1387, figs 5.1-5.2, 5.5-5.6 [fig. 5.5, 5.6 = holotype].

2020 Ancyrodella crosbiensis Kralick. - Kirchgasser in Kirchgasser et al., p. 209, fig. 5h, i.

Diagnosis. - Ancyrodella crosbiensis does not have a marked depression between the posterior end of the free blade and the beginning of the carina. There are 2-5 diagonal rows of nodes on either side of, and converging posteriorly toward the carina at the anterior end of the platform.

Remarks. - In contrast to A. crosbiensis, the Pa element of A. rotundiloba s.s. has a marked depression in which there is a distinct gap in denticulation or tiny nodes between the free blade and carina. Although most illustrated specimens of $A$. crosbiensis have a small pit like that of A. rotundiloba s.s., exceptions which have a pit resembling that of A. pristina are the holotype (Kralick 1994, fig. 5.5) and the specimens of Huddle (1981, pl. 10, figs 6, 14). Ancyrodella rotundiloba s.s. does not have diagonal rows of nodes anteriorly (= rostral ridges of Huddle, 1981, p. b28 and explanation of the specimen in pl. 10, fig. 6).

\section{Ancyrodella pristina Khalymbadzha \& Chernysheva, 1970}

Figure 1N-P

1967 Ancyrodella rotundiloba subsp. A; Uyeno, p. 5, pl. 1, fig. 3 [only; reillustrated under same designation by Uyeno, 1974, pl. 2, fig. 6; figs 7, 9 probably belong to the same species].

1970 Ancyrodella pristina sp. nov.; Khalymbadzha \& Chernysheva, pp. 89, 90, pl. 1, figs 3-8 [figs 5-7= holotype].

1970 Ancyrodella rotundiloba (Bryant). - Kirchgasser, pp. 343 , 344, pl. 65 , figs 5, 6, 9 [fig. $8=$ ?].

1971 Ancyrodella rotundiloba rotundiloba (Bryant). Szulczewski, p. 15, pl. 1, fig. 4 [only].

1974 Ancyrodella rotundiloba binodosa Uyeno. - Uyeno, pp. 24, 25, pl. 1, fig. 2 [only].

1976 Ancyrodella rotundiloba rotundiloba (Bryant). - Druce, pp. 62-64, pl. 9, figs 1-5, 7 [only].

1981 Ancyrodella rotundiloba rotundiloba (Bryant). Bultynck \& Hollard, p. 38, pl. 10, fig. 7.

1981 Ancyrodella rotundiloba rotundiloba (Bryant). Huddle, pp. b19, b20, pl. 1, figs 11-13 [only]. 
1981 Ancyrodella binodosa Uyeno. - Bultynck \& Jacobs, pp. 16, 17, pl. 8, figs 1-14; pl. 9, figs 1, 2, 6 [non figs $3-5,7,8=$ transitional between $A$. binodosa and A. pristina].

1982 Ancyrodella binodosa Uyeno. - Bultynck, p. 56, pl. 1, figs 19-24 [only].

1982 Ancyrodella binodosa Uyeno. - Mouravieff, p. 112, pl. 1, figs 4, 5, 10, 12, 14-20 [only].

1983 Ancyrodella binodosa Uyeno. - Bultynck, p. 165, figs 1.21-1.27, 1.32-1.34.

1985 Ancyrodella rotundiloba (Bryant) early form. - Klapper, pp. 24, 26, 27, pl. 1, figs 1-20; pl. 2, figs 5-12; pl. 3 , figs 5-9 [misprinted as late form; corrected in distributed reprints], 10, 11.

1989 Ancyrodella pristina Khalymbadzha \& Chernysheva. - Sandberg, Ziegler \& Bultynck, pp. 210, 211, figs 2.2-2.4, pl. 1, figs 3, 4, 9, 10, 13,14.

1989 Ancyrodella soluta $\mathrm{n}$. sp.; Sandberg, Ziegler \& Bultynck, pp. 211, 212, figs 2.5-2.7, pl. 1, figs 5, 6, 11, 12 [only].

1989 A. sp. n. - Racki \& Wrzolek, pp. 234, 236, fig. 1 [drawing of specimen in Klapper 1985, pl. 1, figs 11, $12=$ A. pristina $]$.

1992 Ancyrodella rotundiloba (Bryant) early form sensu Klapper (1985)? - Uyeno, p. 128, pl. 15, figs 5, 6, $15,16$.

1992 Ancyrodella rotundiloba (Bryant) early form sensu Klapper (1985). - Uyeno, p. 128, pl. 15, figs 7, 8.

1993 Ancyrodella pristina Khalymbadzha \& Chernysheva. - Racki \& Bultynck, pl. 6, fig. 1; pl. 7, fig. 5 [upper view of same specimen], fig. 6 [=?].

1993 Ancyrodella soluta Sandberg, Ziegler, \& Bultynck. Racki \& Bultynck, pl. 6, figs 2, 3, 7 [fig. 7, because of the pit size, not the outline]; pl. 7, figs 1, 2, 9, 10 [figs $3,11=$ ?, because the outline is that of $A$. rotundiloba s.s., but the pit is not shown].

1993 Ancyrodella pristina Khalymbadzha \& Chernysheva. Ji \& Ziegler, pp. 53, 54, pl. 1, figs 7-9.

1994 Ancyrodella rotundiloba (Bryant) early morphotype. Kirchgasser, pp. 123, 125, pl. 1, figs a-i, pl. 2, figs $\mathrm{a}-\mathrm{k}, \mathrm{n}-\mathrm{p}$.

1994 Ancyrodella rotundiloba (Bryant). - Kralick, p. 1387, figs 4.7, 4.8; 5.3, 5.4, 5.7, 5.8 [only; the pit in fig. 5.7 is transitional between $A$. pristina and A. rotundiloba].

1998a Ancyrodella pristina Khalymbadzha \& Chernysheva. - Spalletta \& Perri, p. 197, pl. 2.1.1, fig. 6.
1999 Ancyrodella pristina Khalymbadzha \& Chernysheva. - Lazreq, p. 60, pl. 3, figs 8, 9, 13.

1999 Ancyrodella soluta Sandberg, Ziegler \& Bultynck. Lazreq, p. 60, pl. 3, fig. 10.

2000 Ancyrodella rotundiloba (Bryant, 1921) early form. Klapper, pl. 1, figs 1, 5 [reillustration of Klapper, 1985, pl. 3, figs 5, 6].

2005 Ancyrodella rotundiloba (Bryant, 1921) early form of Klapper (1985). - Uyeno \& Wendte, p. 163, pl. 1, figs $1,2$.

2005 Ancyrodella rotundiloba (Bryant, 1921) late form of Klapper (1985). - Uyeno \& Wendte, p. 163, pl. 1, figs 4, 5.

2007 Ancyrodella rotundiloba pristina Khalymbadzha \& Chernysheva. - Aboussalam \& Becker, pp. 364, 365, fig. $9 \mathrm{k}, 1$, o-r [interpreted herein as an ontogenetic series, rather than different morphotypes].

2007 Ad. rotundiloba binodosa.-Aboussalam \& Becker, p. 359, fig. 9m, n [i,j may represent an early ontogenetic stage].

2007 Ancyrodella pristina Khalymbadzha \& Chernysheva. Miller, p. 446, fig. 21-y [in 2e and $2 \mathrm{j}$ the pit appears to be too small for this species; in $2 b$ and $2 g$ the pit is covered by basal plate; in fig. $3 \mathrm{~h}, \mathrm{j}$ the pit also seems too small for $A$. pristina].

2007 Ancyrodella rotundiloba. - Over, p. 1202, figs 11.18, 11.21.

2008 Ancyrodella pristina Khalymbadzha \& Chernysheva. Liao \& Valenzuela-Ríos, pp. 2, 3, 7, fig. 6j [6i = ?].

2008 Ancyrodella soluta Sandberg, Ziegler, \& Bultynck. Liao \& Valenzuela-Ríos, p. 7, fig. 6k-p.

2008 Ancyrodella binodosa Uyeno. - Ovnatanova \& Kononova, p. 1080, 1155, pl. 26, fig. 3 [only; figs 1, $2=$ possibly juveniles of $A$. pristina].

2012 Ancyrodella rotundiloba (early morphotype $=$ rot . pristina). - Becker et al., p. 569, fig. 22.7d, e.

2013 Ancyrodella pristina Khalymbadzha \& Chernysheva. - Gouwy, Liao \& Valenzuela-Ríos, p. 323, fig. $61, \mathrm{~m}$.

2013 Ancyrodella pristina "transitional form with Ad. rotundiloba (Bryant, 1921)". - Gouwy, Liao \& Valenzuela-Ríos, p. 332, fig. 6n, o.

2013 Transitional form between Ancyrodella binodosa Uyeno, 1967 and Ancyrodella pristina Khalymbadzha \& Chernysheva, 1970. - Gouwy, Liao \& ValenzuelaRíos, p. 332, fig. 6i, j.

Figure 1. All photograph magnifications are $\times 40$. Abbreviations: see Appendix: Localities of illustrated specimens; FZ $=$ Frasnian Zone. A, B - Ancyrodella alata Glenister et Klapper 1966, lower and upper views of F54956, TH 370-A, FZ 4. • C-F - Ancyrodella nodosa Ulrich et Bassler 1926; C-E - upper views of F54957-54959, WMcP 365-4, 9, 11, FZ 5; F - upper view of F54960, HS 364-18, FZ 11. • G - Ancyrodella hamata Ulrich et Bassler 1926, upper view of F54961, HS 364-71, FZ 13b. • H, I, L - Ancyrodella africana García-López 1981; H, I - upper and lower views of F54962, TH 370-D, FZ 4; L - upper view of F54963, TH 370-B, FZ 4. • J, K - Ancyrodella rugosa Branson et Mehl 1934, upper views of F54964-54965, Capped-Oncolite locality, sample 3, FZ 4. • M - Ancyrodella devonica García-López 1986, upper view of F54966, TH 370-1, FZ 4. • N-P - Ancyrodella pristina Khalymbadzha \& Chernysheva 1970; N - upper view of F54967, Outcamp Hill, FZ 2; O, P - lower and upper views of F54968, Outcamp Hill, FZ 2. Q Q, R - Ancyrodella rotundiloba (Bryant, 1921), lower and upper views of F54969, Outcamp Hill, FZ 2. 

2013 Ancyrodella pristina Khalymbadzha \& Chernysheva.Liao \& Valenzuela-Ríos, pp. 346, 347, fig. 6a, b.

2013 Ancyrodella rotundiloba rotundiloba (Bryant). - Liao \& Valenzuela-Ríos, pp. 347, 348, fig. 6f [only].

2013 Ancyrodella rotundiloba (Bryant, 1921) early form.Gholamalian et al., p. 143, pl. 1, figs 1-13.

2014 Ancyrodella pristina Khalymbadzha \& Chernysheva.Bahrami et al., p. 184, pl. 1, fig. 17.

2016 Ancyrodella rotundiloba pristina Khalymbadzha \& Chernysheva. - Klapper \& Kirchgasser, p. 537, figs 7.5, 7.10.

2017 Ancyrodella pristina Khalymbadja \& Chernyscheva. Ovnatanova et al., pp. 1049, 1050, pl. 11, fig. 7.

2017 Ancyrodella soluta Sandberg, Ziegler \& Bultynck. Ovnatanova et al., pp. 1055, 1056, pl. 29, fig. 6 [only].

2019 Ancyrodella rotundiloba soluta Sandberg, Ziegler \& Bultynck. - Telnova, Soboleva \& Sobolev, p. 259, fig. 4.1.

2019 Ancyrodella rotundiloba pristina Khalimbadzha \& Chernysheva. - Özkan et al., p. 216, figs 6.13, 6.14.

2020a Ancyrodella [as Ad.] rotundiloba pristina. - Becker et al., p. 75, figs 62.17, 62.18.

2020 Ancyrodella [as Ad.] rotundiloba pristina. - Aboussalam et al., p. 148, fig. 20.6.

Diagnosis. - Ancyrodella pristina is distinguished from A. rotundiloba s.s. by having a basal pit that is more extensive laterally. Neither species has well developed secondary keels.

Remarks. - Ancyrodella pristina Khalymbadzha and Chernysheva was proposed as a new species in 1970 (pp. 89, 90, pl. 1, figs 3-8; holotype = figs 5-7). The species was mostly long overlooked until the paper of Sandberg, Ziegler and Bultynck (1989, pp. 210, 211; the exception was Ziegler 1973, p. 35). Sandberg et al. treated the taxon as a separate species of Ancyrodella although some later authors (Aboussalam \& Becker 2007; Klapper \& Kirchgasser 2016 considered pristina as a subspecies of A. rotundiloba). Sandberg et al. (op. cit. fig. 2, a diagram of their evolutionary hypothesis) proposed a further new species termed $A$. soluta, which they regarded as transitional between $A$. pristina and $A$. rotundiloba. The analysis of the current revision, however, indicates that pristina and some of the specimens identified as soluta are intraspecific variants of the one taxon. Compare specimens in Sandberg et al. 1989, p. 199, figs 2.5, 2.7 identified as soluta with fig. 2.4 determined as pristina, as well as pl. 1, figs $3,4,9,10=$ pristina, with pl. 1, figs 5, 6, 11, 12 identified as soluta. Gouwy et al. (2007, p. 389) regarded the soluta holotype "as an extreme form in the range of variation of An. pristina, close to An. rotundiloba". The holotype of A. soluta, however (Sandberg et al. 1989, pl. 2, figs 1,2), fits well within the range of variation of
A. rotundiloba s.s. as considered herein. [A specimen that was termed a "transitional specie (sic) between Ancyrodella rotundiloba pristina and Ancyrodella rotundiloba soluta" by Zhang et al. (2019, p. 9, fig. 6.1) is indeterminate. Without a lower view this specimen cannot be identified with confidence as to whether it is A. pristina or $A$. rotundiloba]. Similarly, without lower views showing the pit size, specimens identified as $A$. soluta (Ji \& Ziegler, 1993, pl. 1, figs 5, 6) cannot be determined whether they are A. pristina or A. rotundiloba. This is exemplified by specimens that have closely similar platform outlines and upper surfaces, but distinctly different pit sizes (Gouwy et al. 2013, fig. 6n, o versus fig. 6p, q)

A second difference from the Sandberg et al. 1989 evolutionary hypothesis is the identification of two specimens shown in their figs 2.8 and 2.10 (also as photographs in pl. 3, figs 1, 2, 8, 9), which were represented as characteristic of Ancyrodella rotundiloba. Instead, these specimens are characteristic of $A$. recta as has been noted previously by Kralick 1994 (p. 1387) and Klapper 2000 (pp. 154, 156). The two species are conspicuously different as shown in Klapper (2000, pl. 1, figs 2-4, $8=$ A. recta; figs $6,7,9-14=A$. rotundiloba, lectotype $=$ figs $13,14)$ [see under $A$. rotundiloba for discussion].

The pit is more extensive laterally in A. pristina than in A. rotundiloba s.s. and is commonly larger, e.g., Klapper, 1985, pl. 1, figs $1,4,6,8,10,14,15,18,20=$ pristina (= "early form" of rotundiloba in the terminology of that paper); pl. 2, figs $6,7,9,11$; pl. 3, figs 5, 8, $10=$ pristina ( 5 and 8 were misprinted as the "late form" but corrected to "early form" in distributed reprints as noted in Klapper \& Kirchgasser 2016, p. 537). In contrast, the pit is smaller in rotundiloba s.s. (so-called "late form" of Klapper 1985, e.g., pl. 2, figs 1, 4, pl. 3, figs 1, 3; Klapper 2000, pl. 1, fig. 1 = pristina, figs $6,11,12,14$ = rotundiloba; Gouwy et al. 2013 , fig. $60=$ pristina, fig. $6 \mathrm{q}=$ rotundiloba s.s.). The platform outline is generally more nearly triangular in A. pristina versus more heart-shaped in A. rotundiloba s.s. although there is some overlap in shape. Consequently, the species level distinction is more reliably based on the pit. Bultynck \& Jacobs (1981, pl. 8, figs 1-12, their alpha morphotype of $A$. binodosa) illustrated an excellent ontogenetic series of $A$. pristina.

\section{Ancyrodella recta Kralick, 1994}

1957 Ancyrodella rotundiloba (Bryant). - Bischoff \& Ziegler, p. 42, pl. 16, figs 5, 10, 12, 17 [only].

1958 Ancyrodella rotundiloba (Bryant). - Ziegler, pp. 44, 45, pl. 11, fig. 12 [only].

1959 Ancyrodella rotundiloba (Bryant). - Krebs, p. 384, pl. 1, fig. 15 .

1966 Ancyrodella rotundiloba alata $\mathrm{n}$. subsp.; Glenister \& Klapper, pp. 799, 800, pl. 86, figs 1, 2 [only]. 
1967 Ancyrodella rotundiloba (Bryant). - Müller \& Clark, p. 908 , pl. 115 , fig. 8 ; text-figs 5 d, 6 i [there are two figures labeled $\mathrm{i}$, the upper one appears to be $A$. recta , 6k-m, p, r, x [only].

1967 Ancyrodella rotundiloba (Bryant). - Clark \& Ethington, pp. 29, 30, pl. 2, figs 9, 13 [only].

1969 Ancyrodella rotundiloba rotundiloba (Bryant). - Pölsler, p. 404, pl. 4, figs 5, 6 [only].

1970 Ancyrodella rotundiloba alata Glenister \& Klapper. Khalymbadzha \& Chernysheva, pp. 92-94, pl. 2, figs 1,2 [only].

1970b Ancyrodella rotundiloba alata Glenister \& Klapper. Seddon, p. 94, pl. 7, fig. 4 [only].

1971 Ancyrodella rotundiloba rotundiloba (Bryant). Szulczewski, p. 15, pl. 2, fig. 6 [only].

1973 Ancyrodella rotundiloba rotundiloba (Bryant). - Ziegler, pp. 29-31, Ancyro pl. 1, fig. 2 [only; reillustration of Ziegler, 1958, pl. 11, fig. 12b].

1974 Ancyrodella rotundiloba alata Glenister \& Klapper. Uyeno, p. 24, pl. 1, fig. 3 [only].

1976 Ancyrodella rotundiloba alata Glenister \& Klapper. Druce, pp. 64, 65, pl. 11, fig. 4 [only].

1980 Ancyrodella rotundiloba alata Glenister \& Klapper.Klapper, p. 112, pl. 3, fig. 33.

1981 Ancyrodella rotundiloba aff. alata Glenister \& Klapper.Bultynck \& Hollard, p. 38, pl. 9, figs 15, 16 [only].

1981 Ancyrodella rotundiloba alata Glenister \& Klapper, 1966. - Huddle, pp. b20, b21, pl. 2, figs 20-24 [only; pl. 1, figs 25-27 are too small for confident identification].

1981 Ancyrodella rotundiloba rotundiloba (Bryant). Bultynck \& Jacobs, pp. 17, 18, pl. 10, fig. 9 [only].

1982 Ancyrodella rotundiloba rotundiloba (Bryant). Bultynck, p. 57, pl. 2, fig. 3 [only].

1983 Ancyrodella rotundiloba rotundiloba. - Bultynck, p. 165, fig. 1.37 [only; = reillustration of Bultynck 1982, pl. 2, fig. 3].

1985 Ancyrodella alata Glenister \& Klapper, early form. Klapper, pp. 27, 28, pl. 4, figs 5, 6 [only], pl. 5, figs 7-10, 13-16 [only]; pl. 6, figs 9-12.

1985 Ancyrodella alata Glenister \& Klapper, late form. Klapper, pp. 27, 28, pl. 6, figs 5-8 [only].

1987 Ancyrodella rotundiloba (Bryant). - Fuchs, pl. 3, fig. 2.

1989 Ancyrodella rotundiloba (Bryant). - Sandberg, Ziegler \& Bultynck, pp. 212, 213, pl. 2, figs 9, 10 [only]; pl. 3, figs 1, 2 [reillustration of Ziegler 1958, pl. 11, fig. 12; drawing of same specimen on text-fig. 2.8]; figs 8, 9 [reillustration of Bischoff \& Ziegler 1957, pl. 16, fig. 10; drawing of same specimen on text-fig. 2.10].

1989 Ancyrodella rotundiloba (Bryant). - Vandelaer et al., p. 331, pl. 1, fig. 1 .

1992 Ancyrodella alata Glenister \& Klapper. - Yatskov \& Kuz'min, p. 89, pl. 2, fig. 4 [only].
1993 Ancyrodella alata Glenister \& Klapper. - Racki \& Bultynck, pl. 9, fig. 3 [only].

1993 Ancyrodella africana García-López. - Racki \& Bultynck, pl. 9, fig. 6 [only].

1994 Ancyrodella rotundiloba (Bryant). - Weary \& Harris, p. 224, pl. 2, figs 15-18 [only].

1994 Ancyrodella rotundiloba (Bryant). - Sandberg, Hasenmueller \& Rexroad, p. 250, pl. 1, fig. 7.

1994 Ancyrodella recta n. sp.; Kralick, p. 1387, 1390, figs 3.5, 3.6, 3.11, 3.12, 4.11, 4.12, 6.1, 6.2, 6.5, 6.6, 6.9, 6.10 [figs 6.1, 6.2 = holotype]

2000 Ancyrodella recta Kralick. - Klapper, pp. 154, 156, 158, pl. 1, figs 2, 3 [reillustration of holotype]; figs 4, 8 [reillustration of Klapper 1985, pl. 6, figs 7, 8].

2000 Ancyrodella rotundiloba (Bryant). - Gouwy \& Bultynck, p. 40, pl. 1, figs 1, 2.

2001 Ancyrodella alata Glenister \& Klapper. - Savage \& Yudina, pp. 287, 288, pl. 1, figs 10-12 [only].

2001 Ancyrodella cf. A. alata Glenister \& Klapper. - Savage \& Yudina, p. 288, pl. 1, figs 1-3 [only].

2004 Ancyrodella recta Kralick. - Klapper, Uyeno et al., p. 377, figs 5.1, 5.2, 5.7-5.9.

2005 Ancyrodella recta Kralick. - Uyeno \& Wendte, p. 163, pl. 1, figs 12, 13.

2007 Ancyrodella recta Kralick. - Miller, pp. 448, 449, figs 4a-y, 5a, 5d-y.

2008 Ancyrodella rotundiloba - Ancyrodella recta. - Liao \& Valenzuela-Ríos, pp. 7, 13, fig. 6q, r.

2013 Ancyrodella rotundiloba alata Glenister \& Klapper. Liao \& Valenzuela-Ríos, p. 347, figs 6c, d.

2016 Ancyrodella recta Kralick. - Klapper \& Kirchgasser, p. 552, figs $7.15,7.16$.

2017 Ancyrodella recta Kralick. - Ovnatanova et al., pp. 1050, 1053, pl. 14, figs 3, 5 [only]; pl. 16, fig. 5 [only]; pl. 23, figs 2, 3, 8 [fig. 7 = ?]; pl. 31, fig. 4 .

2017 Ancyrodella rugosa Branson \& Mehl. - Ovnatanova et al., p. 1055, pl. 9, fig. 3.

2020 Ancyrodella recta Kralick. - Kirchgasser in Kirchgasser et al., p. 210, figs 6k, 9c-e.

2020 Ancyrodella alata Glenister \& Klapper. - Kirchgasser in Kirchgasser et al., p. 210, fig. 6c [only].

Diagnosis. - Ancyrodella recta has straight margins of the anterior inner platform and commonly curved outer margins, a small basal pit, and thin short secondary keels, the inner one directed anteriorly, the outer directed laterally.

Remarks. - A significant number of identifications of Ancyrodella rotundiloba prior to the establishment of A. recta by Kralick (1994) resulted in a heterogeneous taxonomic concept of the former species. This has since been clarified by the recognition of $A$. recta (see respective synonymies). For the main comparison with $A$. rotundiloba s.s., see under the latter. In $A$. recta, the anterior 
outer platform is usually curved, but it can be straight (e.g., Kralick 1994, figs 3.11, 6.9). It is always curved in A. rotundiloba s.s.

Miller's 2007 paper represents a major contribution to the ontogenetic variation in the early species of Ancyrodella (that is, A. pristina, A. rotundiloba, and A. recta). All the specimens in his figure 5 (except $b, c)$ represent A. recta and are from sample 8 , which also has $A$. rotundiloba (fig. $1 ; 5 \mathrm{~b}, \mathrm{c}$ ) but not $A$. pristina. The distinctive juveniles of $A$. recta in figure 5 are matched by those in figure 4 and were so identified by Miller, but differ from the juveniles in ontogenetic series 2 from sample 7 (fig. 3).

\section{Ancyrodella rotundiloba (Bryant, 1921) s.s.}

Figure 1Q, R

1921 Polygnathus rotundilobus Spec. Nov.; Bryant, pp. 26, 27, pl. 12, figs $1-6$, text-fig. 7 [fig. $1=$ lectotype selected by Ziegler 1958, p. 44].

1933 Polygnathus tuberculata Hinde, 1879. - Branson \& Mehl, pp. 148, 165, pl. 11, fig. 9 [non fig. 2 = lectotype of Polygnathus tuberculatus Hinde, selected by Bryant 1921, p. 25; see Klapper 2017, p. 219].

1934 Polygnathus rotundiloba Bryant. - Huddle, pp. 102, 103, pl. 8, figs 36, 37.

1957 Ancyrodella rotundiloba (Bryant). - Bischoff \& Ziegler, p. 42 , pl. 16, fig. 7 [only].

1966 Ancyrodella rotundiloba rotundiloba (Bryant). Glenister \& Klapper, p. 799, pl. 85, figs 9-13.

1967 Ancyrodella rotundiloba (Bryant). - Müller \& Clark, p. 908 , pl. 116, fig. 1 [non figs $2-5=$ ? A. sp.]; text-fig. 5a-c, e, non 5d = A. recta Kralick, 1994].

1967 Ancyrodella rotundiloba subsp. A. - Uyeno, p. 5, pl. 1, fig. 6 [only]; [reillustrated by Uyeno 1974, pl. 2, fig. 8].

? 1967 Ancyrodella rotundiloba subsp. A. - Uyeno, p. 5, pl. 1, fig. 1 [specimen has pit not unlike that of $A$. pristina, but platform outline is that of $A$. rotundiloba; reillustrated by Uyeno 1974, pl. 2, fig. 1]

1970 Ancyrodella rotundiloba rotundiloba (Bryant). - Khalymbadzha \& Chernysheva, pp. 91, 92, pl. 1, figs 9-12.

1972 Ancyrodella rotundiloba rotundiloba (Bryant). Klapper \& Philip, p. 99, pl. 2, figs 1-5 [multielement reconstruction].

1973 Ancyrodella rotundiloba rotundiloba (Bryant). - Ziegler, pp. 29-31, Ancyro pl. 1, fig. 1 [only; reillustration of lectotype].

1976 Ancyrodella rotundiloba rotundiloba (Bryant). - Druce, pp. 62-64, pl. 9, fig. 6 [only]; pl. 10, figs 1-3; pl. 12, fig. 1.

1976 Ancyrodella rotundiloba alata Glenister \& Klapper, 1966. - Druce, pp. 64, 65, pl. 11, figs 1-3 [only].

1980 Ancyrodella rotundiloba rotundiloba (Bryant). Klapper, p. 112, pl. 3, figs 34, 35.
1981 Ancyrodella rotundiloba rotundiloba (Bryant). - Huddle, pp. b19, b20, pl. 1, figs 1-3, 6-8, 16, 17 [only; figs 1,2 = reillustration of lectotype; non figs 4, 5, 14, $15=$ ? A. triangulata Kralick; non figs 11-13 = A. pristina]; pl. 3, figs 20, 21.

1981 Ancyrodella rugosa Branson \& Mehl. - Huddle, pp. b21, b22, pl. 3, figs 16, 17 [only].

1981 Ancyrodella rotundiloba rotundiloba (Bryant). Bultynck \& Jacobs, pp. 17, 18, pl. 10, figs 1-8 [only].

1982 Ancyrodella rotundiloba rotundiloba (Bryant). - Bultynck, pp. 56, 57, pl. 1, figs 26, 27; pl. 2, figs 1, 2 [only].

1982 Ancyrodella rotundiloba rotundiloba (Bryant). Mouravieff, p. 113, pl. 2, fig. 4.

1983 Ancyrodella rotundiloba rotundiloba (Bryant). Bultynck, p. 165, figs 1.35, 1.36 [only; $1.35=$ reillustration of Bultynck 1982, pl. 1, fig. 26].

1985 Ancyrodella rotundiloba (Bryant) late form. - Klapper, pp. $24,26,27$, pl. 2, figs $1-4$; pl. 3, figs $1-4,12$; pl. 4, figs 9-12; pl. 8, figs 9, 10; pl. 11, figs 3, 4; textfig. $3 \mathrm{e}-\mathrm{j}, \mathrm{m}, \mathrm{n}$.

1989 Ancyrodella rotundiloba (Bryant). - Sandberg, Ziegler \& Bultynck, pp. 212, 213, text-fig. 2.9 [reillustration of Bischoff \& Ziegler 1957, pl. 16, fig. 7; non text-figs 2.8, 2.10 = A. recta]; pl. 3, figs 5, 6 [reillustration of same specimen as in text-fig. 2.9]; fig. $7=$ [reillustration of lectotype].

1989 Ancyrodella soluta n. sp. - Sandberg, Ziegler \& Bultynck, pp. 211, 212, pl. 2, figs 1-4 [only; figs $1,2=$ holotype].

1989 Ancyrodella rotundiloba (Bryant). - Racki \& Wrzolek, pp. 234, 236, text-fig. 1, specimen from bed 46 [drawing of specimen in Klapper 1985, pl. 4, figs 11, 12].

1994 Ancyrodella rotundiloba (Bryant) late morphotypes. Kirchgasser, p. 125, pl. 2, figs 1, m, q, r.

1994 Ancyrodella rotundiloba (Bryant). - Weary \& Harris, p. 224, pl. 2, figs 9, 10, 19-21 [only].

1994 Ancyrodella rotundiloba (Bryant). - Kralick, p. 1387, figs 3.15-3.24 [3.21, 3.22= reillustration of lectotype]; figs 5.9-5.11 [only].

2000 Ancyrodella rotundiloba (Bryant) late form. - Klapper, p. 158, pl. 1, figs 6, 7, 9-14 [10, $11=$ reillustration of Klapper 1985, pl. 4, figs 11, 12; 13, 14 = reillustration of lectotype].

2004 Ancyrodella rotundiloba (Bryant) late form. - Klapper et al., p. 377, fig. 5.6.

2007 Ancyrodella rotundiloba (Bryant, 1931 [sic]). - Miller, pp. 447, 449, figs 3a-g, k, 1; 5b, c.

2013 Ancyrodella rotundiloba (Bryant) late form of Klapper (1985). - Gouwy, Liao \& Valenzuela-Ríos, pp. 323, 324, fig. 6p, q.

2013 Ancyrodella rotundiloba rotundiloba (Bryant). - Liao \& Valenzuela-Ríos, pp. 347, 348, fig. 6e [only].

2016 Ancyrodella rotundiloba rotundiloba (Bryant). Klapper \& Kirchgasser, pp. 534, 537, figs 7.8, 7.9. 
2017 Ancyrodella rotundiloba (Bryant). - Ovnatanova et al., p. 1053, 1055, pl. 14, fig. 1 [only].

2017 Ancyrodella soluta Sandberg, Ziegler \& Bultynck. Ovnatanova et al., pp. 1055, 1056, pl. 5, fig. 8; pl. 23, fig. 1 [only; figs 4-6=A. sp., 3 juveniles without lower views].

2019 Ancyrodella rotundiloba rotundiloba Bryant [sic]. Telnova, Soboleva \& Sobolev, p. 259, fig. 4.3.

2020 Ancyrodella rotundiloba rotundiloba Branson \& Mehl [sic]. - Kirchgasser in Kirchgasser et al., p. 210, fig. 6i.

Diagnosis. - Ancyrodella rotundiloba s.s. has a mediumsized pit and lacks well developed secondary carinae and secondary keels. Only exceptionally are there a few small nodes or the faint suggestion of incompletely developed keels in that position.

Remarks. - In contrast to Ancyrodella rotundiloba s.s., $A$. recta has a straight anterior inner platform margin, a distinctly smaller pit, and thin secondary keels. The latter are lacking in $A$. rotundiloba, although exceptionally there are either a few small nodes or incipient, extremely weakly developed secondary keels under the anterior lobes. The anterior inner platform margin of the latter is always curved. Furthermore in A. rotundiloba, there is a marked depression between the posterior end of the free blade and the carina that is occupied by either a small gap in denticulation or one to two tiny nodes. In $A$. recta, however, this denticulation gap is shorter, equivalent to the space of one tiny node that is characteristically absent. The denticulation gap in A. rotundiloba was first noted and shown by Müller \& Clark (1967, p. 905, text-fig. 2).

The specimen illustrated by Soboleva \& Sobolev (2019, fig. 6n, o) appears to be transitional between Ancyrodella rotundiloba and A. rugosa. The faint secondary keels are much better developed than in the former and are in the pattern but not nearly as strong as in the latter species.

\section{Ancyrodella rugosa Branson \& Mehl, 1934}

Figure 1J, K

1934 Ancyrodella rugosa n. sp.; Branson \& Mehl, p. 239, pl. 19, figs 15, 17 [= holotype].

1957 Ancyrodella rugosa Branson \& Mehl. - Bischoff \& Ziegler, p. 42, pl. 16, fig. 13.

1958 Ancyrodella rugosa Branson \& Mehl. - Ziegler, p. 45.

1959 Ancyrodella rugosa Branson \& Mehl. - Krebs, p. 384, pl. 1, fig. 14.

1968 Ancyrodella rugosa Branson \& Mehl. - Pollock, p. 428 , pl. 61, fig. 1.

1970b Ancyrodella rugosa Branson \& Mehl. - Seddon, p. 94, pl. 7, figs 2, 3 .

1971 Ancyrodella sinecarina sp.n.; Szulczewski, pp. 16, 17, pl. 1, figs 5, 6 .
1971 Ancyrodella rotundiloba rotundiloba (Bryant). Szulczewski, p. 15, pl. 1, fig. 3 [only].

1974 Ancyrodella gigas Youngquist. - Uyeno, pp. 23, 24, pl. 1, figs $1,8,9$.

1976 Ancyrodella rugosa Branson \& Mehl. - Druce, p. 66, pl. 3, fig. 4.

1979 Ancyrodella rotundiloba rotundiloba (Bryant). Baliński, p. 75, pl. 20, figs 6, 7.

1981a Ancyrodella rugosa Branson \& Mehl. - Perri \& Spalletta, p. 294, pl. 1, fig. 7.

1981 Ancyrodella rugosa Branson \& Mehl. - Huddle, pp. b21, b22, pl. 3, figs 1-15, 18, 19 [only].

1982 Ancyrodella rugosa Branson \& Mehl. - Bultynck, pp. 38, 57, pl. 2, figs 11, 13-16.

1983 Ancyrodella rugosa Branson \& Mehl. - Bultynck, p. 165, figs 1.30, 1.31 [= reillustration of Bultynck 1982, figs 13b, 14, respectively].

1985 Ancyrodella rugosa Branson \& Mehl. - Klapper, p. 30, pl. 11, figs 1, 2, 5-14, text-fig. $3 \mathrm{u}$, v.

1989 Ancyrodella rugosa Branson \& Mehl. - Vandelaer et al., p. 331, pl. 1, figs 3, 4 .

1991 Ancyrodella rugosa Branson \& Mehl. - Uyeno, p. 158, pl. 4, figs 10, 11.

1992 Ancyrodella rugosa Branson \& Mehl. - Yatskov \& Kuz'min, p. 89, pl. 2, fig. 2 [only; fig. $5=$ indet. juvenile].

1993 Ancyrodella rugosa Branson \& Mehl. - Racki \& Bultynck, pl. 8, figs 9-12.

1994 Ancyrodella rugosa Branson \& Mehl. - Weary \& Harris, p. 217, pl. 1, figs 14, 15.

1994 Ancyrodella aff. An. rugosa Branson \& Mehl. - Weary \& Harris, p. 217, pl. 2, fig. 22.

1994 Ancyrodella rugosa Branson \& Mehl. - Kralick, p. 1393, figs 3.7, 3.8, 3.13, 3.14, 4.9, 4.10.

2000 Ancyrodella rugosa Branson \& Mehl. - Gouwy \& Bultynck, pp. 40, 42, pl. 1, figs 3-6.

2001 Ancyrodella rotundiloba (Bryant). - Savage \& Yudina, p. 288, pl. 2, figs 1-4.

2003 Ancyrodella rugosa Branson \& Mehl. - Over et al., p. 222, pl. 1, figs 18, 19 .

2005 Ancyrodella rugosa Branson \& Mehl. - Uyeno \& Wendte, p. 163, pl. 1, figs 10, 11.

2006 Ancyrodella rugosa Branson \& Mehl. - Pisarzowska et al., p. 625, fig. 13a.

2007 Ancyrodella rugosa Branson \& Mehl. - Gouwy et al., p. 389, fig. $15 \mathrm{~h}$.

?2007 Ancyrodella rugosa. - Over, p. 1202, figs 11.11, 11.19 $[11.11=$ ? A. lobata $]$.

2016 Ancyrodella rugosa Branson \& Mehl. - Klapper \& Kirchgasser, p. 534, figs 7.13, 7.14, 7.17, 7.18.

Diagnosis. - Ancyrodella rugosa has two anteriorly directed secondary carinae and secondary keels, many nodes of uniform size, and a heart-shaped platform outline. 
Remarks. - The Pa element of Ancyrodella rugosa has a similar platform outline to that of $A$. rotundiloba s.s. The crucial difference, however, is the distinct development of the two anteriorly directed secondary carinae and secondary keels in A. rugosa, as opposed to only a few small nodes or incipient, weakly developed keels in A. rotundiloba. Ancyrodella rugosa also differs in having many more nodes of uniform size on the platform. The gap between the free blade and the carina is generally more prominent in A. rugosa, but it also contains one to two small nodes as in Ancyrodella rotundiloba s.s.

The many more nodes of uniform size in A. rugosa contrasts with that in $A$. nodosa, in which there is a row of nodes parallel to, and on either side of the posterior carina. The specimen identified as A. rugosa by Dzik (2002, fig. 25c; Dzik et al. 2018, fig. 3p) has both the quasitrapezoidal platform outline of $A$. lobata (see remarks there) and a row of separated nodes bisecting the outer platform margin just posterior of midlength, in contrast with its absence in $A$. rugosa.

The specimen identified as $A$. sp. cf. A. rugosa by Uyeno $(1991$, pl. 4, figs 8,9$)$ has a platform outline like that of $A$. recta, but the prominent gap between the free blade and the carina is a characteristic of $A$. rugosa. The specimen is considered as intermediate between the two species. Importantly, this prominent gap is absent in A. nodosa.

\section{Ancyrodella triangulata Kralick, 1994}

1981 Ancyrodella rotundiloba alata Glenister \& Klapper.Huddle, pp. b20, b21, pl. 1, figs 9, 10, 23, 24 [only].

? 1981 Ancyrodella rotundiloba rotundiloba (Bryant). Huddle, pp. b19, b20, pl. 1, figs 4, 5, 14, 15 [only].

1981 Ancyrodella rugosa Branson \& Mehl. - Huddle, pp. b21, b22, pl. 1, figs 18, 19 [only].

1985 Ancyrodella alata Glenister \& Klapper. - Klapper, pp. 27, 28, pl. 5, figs 9, 10 [only].

1992 Ancyrodella rotundiloba (Bryant). - Yatskov \& Kuz'min, p. 89, pl. 2, fig. 3.

1994 Ancyrodella triangulata n. sp.; Kralick, pp. 1390, 1393, figs 3.3, 3.4, 3.9, 3.10, 4.1-4.4, 6.3, 6.4, 6.7, 6.8, 6.11, 6.12 [figs $11,12=$ holotype, same as $3.3,3.4$ ].

2005 Ancyrodella triangulata Kralick. - Uyeno \& Wendte, p. 163, pl. 1, figs 6, 7 .

2017 Ancyrodella recta Kralick. - Ovnatanova et al., pp. 1050, 1053, pl. 14, figs 2, 4, 6 [only]; pl. 16, fig. 1 [only].

2019 Ancyrodella triangulata. - Zhang et al., p. 9, fig. 6.2.

Diagnosis. - In Ancyrodella triangulata both the secondary carinae and secondary keels are directed anteriorly and both the outer and inner platform margins are straight.
Remarks. - Ancyrodella triangulata differs from $A$. recta in the secondary carinae and secondary keel patterns. Both structures are directed anteriorly in A. triangulata, whereas only the inner ones are so directly in $A$. recta and the outer ones are directly laterally.

\section{Ancyrodella alata Group}

The group includes Ancyrodella africana s.s., A. devonica, A. alata, and A. pramosica.

\section{Ancyrodella africana García-López, 1981 s.s. \\ Figures 1H, I, L}

1966 Ancyrodella rotundiloba (Bryant) n. subsp.; Krebs \& Ziegler, p. 736, pl. 1, figs 8, 9 [only].

1976 Ancyrodella rotundiloba rotundiloba (Bryant). - Druce, p. 62-64, pl. 9, fig. 4 [only].

1978 Ancyrodella rotundiloba alata Glenister \& Klapper. Orchard, p. 928, pl. 114, figs 29, 30 [only].

1981 Ancyrodella africana n. sp.; García-López, pp. 264, 265, pl. 1, figs 1-14 [figs 1-3 = holotype].

1982 Ancyrodella rugosa Branson \& Mehl. - Mouravieff, p. 114, pl. 3, fig. 2.

1982 Ancyrodella gigas Youngquist. - Mouravieff, p. 114, pl. 3, fig. 4, 5, 7.

1985 Ancyrodella africana García-López. - Klapper, pp. 28, 29, pl. 8, figs 15-18 [only], pl. 9, figs 1-8 [only].

1985 Specimens transitional between $A$. africana GarcíaLópez and $A$. gigas Youngquist. - Klapper, p. 34, pl. 10 , figs $7,8,11,12$, text-figs $3 \mathrm{cc}-$ dd [same as 7,8$]$.

1986 Ancyrodella africana García-López. - García-López, p. 453, pl. 2, figs 10-23 [same illustrations as in her 1981 paper, figs $10-12=$ holotype], text-fig. 3 .

1986 Ancyrodella mouravieffi n. sp.; García-López, p. 449, pl. 1, figs 17-24 [figs 17-20= holotype], pl. 2, figs $1-6$, text-fig. 3.

1986 Ancyrodella rugosa Branson \& Mehl. - Bultynck, p. 276, pl. 1, figs 7, 8 .

1987 Ancyrodella africana García-López. - García-López, pp. 57, 58, pl. 2, figs $8-19[8,9=$ holotype and $=10$, 11 of her 1986 paper; $10,11=13,14$ of her 1986 paper; $12,13=16,17 ; 14,15=18,19 ; 16,17=20$, $21 ; 18,19=22,23$ ], text-fig. 11 [see synonymy].

1987 Ancyrodella mouravieffi García-López. - García-López, pp. 63, 64, pl. 1, figs 13-21 [13-17= holotype], pl. 2, figs 1-4, text-fig. 11 .

1989 Ancyrodella africana García-López. - Vandelaer et al., p. 329 , pl. 1, figs 6,7 .

1989 Ancyrodella gigas Youngquist beta morphotype. Vandelaer et al., pp. 329, 330, pl. 2, fig. 7 [only].

1993 Ancyrodella africana García-López. - Racki \& Bultynck, pl. 9, fig. 8 [only]. 
1993 Ancyrodella pramosica Perri \& Spaletta [sic]. - Racki \& Bultynck, pl. 9, fig. 5 .

1993 Ancyrodella gigas Youngquist. - Ji \& Ziegler, p. 52, pl. 1, fig. 12 [non fig. 11 = indet. fragment].

1999 Ancyrodella rotundiloba (Bryant). - Lazreq, p. 60, pl. 3, figs 14, 15 [only].

2000 Ancyrodella africana García-López. - Gouwy \& Bultynck, p. 40, pl. 1, figs 7, 8.

2002a Ancyrodella africana [transitional with] Ancyrodella gigas. - García-López \& Sanz-López, p. 160, pl. 2, figs $12,13$.

2002a Ancyrodella africana García-López. - García-López \& Sanz-López, p. 160, pl. 2, fig. 14.

2002b Ancyrodella africana García-López. - García-López \& Sanz-López, pp. 198, 200, pl. 2, figs 25, 26 [reillustration of García-López 1981, pl. 1, figs 4, 5], pl. 3, figs 1, 2 [reillustration of García-López 1981, pl. 1, figs 11, 12].

2002b Ancyrodella mouravieffi García-López. - García-López \& Sanz-López, p. 198, pl. 2, figs 23, 24 [= reillustration of holotype, García-López 1986, pl. 1, figs 17, 18].

2003 Ancyrodella africana García-López. - Over et al., p. 222, pl.1, fig. 4 .

2007 Ancyrodella africana García-López. - Gouwy et al., p. 388 , fig. 151.

2007 Ancyrodella alata Glenister \& Klapper late form of Klapper, 1989. - Gouwy et al., p. 388, fig. 15 i [only].

2007 Ancyrodella africana. - Over, p. 1202, fig. 11.20.

2009 Ancyrodella pristina Khalymbadzha \& Chernysheva. Li et al., p. 530, pl. 1, figs 6, 7.

2012 Ancyrodella africana García-López. - Liao \& Valenzuela-Ríos, pp. 821-823, fig. 4a-1.

2012 Ancyrodella mouravieffi García-López. - Liao \& Valenzuela-Ríos, pp. 824, 826, fig. 5i-1.

2012 Ancyrodella devonica García-López. - Liao \& Valenzuela-Ríos, pp. 823, 824, fig. 4m-p.

2013 Ancyrodella africana García-López. - Gholamalian et al., p. 143, pl. 1, figs 20, 21.

2014 Ancyrodella africana García-López. - RodríguezCañero \& Martín-Algarra, p. 48, fig. 9.19.

2014 Ancyrodella mouravieffi García-López. - RodríguezCañero \& Martín-Algarra, p. 48, fig. 9.16.

2015 Ancyrodella africana García-López. - Becker \& Aboussalam, p. 118, pl. aii-2, figs 6, 7.

2017 Ancyrodella africana García-López. - Ovnatanova et al., pp. 1041, 1045, pl. 11, figs 8, 10 [only].

2020a Ancyrodella [as Ad.] africana. - Becker et al., p. 75, fig. $62.19[62.20=$ ?].

2020 Ancyrodella [as Ad.] africana. - Aboussalam et al., p. 149 , fig. 20.12 .

Diagnosis. - In Ancyrodella africana the platform outline is distinctly asymmetrical in that the inner lobe extends farther to the anterior than the outer lobe and they are of different shape. The outer lobe has an extra secondary keel only in some specimens. The inner secondary keel is directed anteriorly, the outer one(s) directed laterally.

Remarks. - The platform outline of the two species, $A n$ cyrodella africana and A. mouravieffi, of García-López $(1986,1987)$ is essentially the same. The specimens of A. mouravieffi in the cited papers are larger than those of A. africana (they are illustrated at different magnifications) suggesting that those of the former represent later ontogenetic stages. There is a short accessory keel on the outer lobe in some specimens of $A$. africana but it is lacking in others, as well as in A. mouravieffi (see text-fig. 11 of the 1987 paper). The inner lobe extends farther to the anterior than the outer lobe making the outline highly asymmetrical in both species. Furthermore, the two lobes are of different shape. The platform outline is viewed here as the most highly weighted character for species separation, suggesting their synonymy.

The specimen of Gouwy \& Bultynck (2000, pl. 1, figs 7,8$)$ is highly representative of $A$. africana s.s. The specimens illustrated by Klapper (1985, pl. 10, figs $7,8,11,12$ ) because of their platform outline are interpreted here as large growth stages of $A$. africana s.s. The specimens of Mouravieff (1982, pl. 3, figs 2, 7) and Bultynck (1986, pl. 1, figs 7, 8) are closely comparable and interpreted to represent this late ontogenetic stage.

\section{Ancyrodella devonica García-López, 1986}

Figure 1M

? 1967 Ancyrodella rotundiloba (Bryant). - Clark \& Ethington, pp. 29, 30, pl. 2, fig. 10 [only].

1969 Ancyrodella rotundiloba rotundiloba (Bryant). Pölsler, p. 404, pl. 4, figs 7, 8 [only].

1981 Ancyrodella rotundiloba aff. alata Glenister \& Klapper.Bultynck \& Hollard, p. 38, pl. 10, fig. 8 [only].

1985 Ancyrodella gigas Youngquist. - Klapper, p. 29, pl. 10, figs 3-6 [only].

1985 Ancyrodella africana García-López. - Klapper, pp. 28, 29, pl. 8, figs 11-14, 19-22 [only], pl. 9, figs 9-16 [only], text-figs $3 \mathrm{~s}, \mathrm{t}$, aa-bb [s, t same as pl. 8, figs 20, 19; aa-bb same as pl. 9, figs 12, 11 , respectively].

1985 Ancyrodella alata Glenister \& Klapper, early form. Klapper, pp. 27, 28, pl. 5, figs 1-6 [only].

1986 Ancyrodella devonica n. sp.; García-López, p. 448, pl. 3, figs 1-10 [figs 1-3=holotype], text-fig. 3 .

1987 Ancyrodella devonica García-López. - García-López, pp. 60,61 , pl. 3, figs 1-6 [1-3= holotype], text-fig. 11 [see synonymy].

1993 Ancyrodella africana García-López. - Racki \& Bultynck, pl. 9, fig. 7 [only].

2002b Ancyrodella devonica García-López. - García-López 
\& Sanz-López, p. 200, pl. 3, figs 3, 4 [= reillustration of holotype, García-López 1986, pl. 3, figs 1, 2].

2005 Ancyrodella africana García-López. - Uyeno \& Wendte, p. 163, pl. 1, figs 14, 15.

2006 Ancyrodella africana García-López. - Pisarzowska et al., p. 625, fig. 13c.

2016 Ancyrodella africana García-López. - Klapper \& Kirchgasser, pp. 534, 552, figs 7.3, 7.4.

2017 Ancyrodella africana García-López. - Ovnatanova et al., pp. 1041, 1045, pl. 15, figs 1, 6 [only].

Diagnosis. - Ancyrodella devonica is closely similar to A. africana s.s. but the anterior lobes are more nearly symmetrical in the former. Both secondary keels, if well developed, may be directed slightly to the anterior.

Remarks. - García-López (1987, p. 60) synonymized the small specimens of Klapper (1985, pl. 10, figs 3-6) in A. devonica. Although those specimens were placed in A. nodosa by Klapper \& Kirchgasser (2016, p. 537) they show the definitive outline of $A$. devonica.

Additionally, Klapper (1985, pl. 8, figs 11-14, 19-22, pl. 9, figs 9-16), by inclusion of the specimens cited, expanded the concept of Ancyrodella africana, as correctly questioned by García-López (1987, pp. 57, 58). I agree that these specimens do not belong in $A$. africana s.s. and by their inclusion herein in A. devonica to some extent expands the concept of that species. However, the Montagne Noire specimens (Klapper 1985, pl. 8, figs $11,12,20,21$ and pl. 9, figs 11, 12) in the very slight asymmetry of the platform outline provide a relationship with the types of $A$. devonica.

\section{Ancyrodella alata Glenister \& Klapper 1966}

Figure 1A, B

1966 Ancyrodella rotundiloba alata n. subsp.; Glenister \& Klapper, pp. 799, 800, pl. 85, figs 1-8 [only; figs 7, 8 = holotype].

1969 Ancyrodella rotundiloba alata Glenister \& Klapper.Pölsler, p. 404, pl. 4, figs 1-4.

1970 Ancyrodella rotundiloba alata Glenister \& Klapper. Khalymbadzha \& Chernysheva, pp. 92-94, pl. 2, figs 3-9 [only].

1970b Ancyrodella rotundiloba alata Glenister \& Klapper. Seddon, p. 98, pl. 9, figs 5, 6 [only].

1972 Ancyrodella rotundiloba alata Glenister \& Klapper. Klapper \& Philip, p. 99, pl. 2, figs 6-13 [multielement reconstruction].

1973 Ancyrodella rotundiloba alata Glenister \& Klapper.Ziegler, pp. 33, 34, Ancyro pl. 1, fig. 3 [reillustration of holotype].

1974 Ancyrodella rotundiloba alata Glenister \& Klapper.Uyeno, p. 24, pl. 1, fig. 7 [only].
1979 Ancyrodella rotundiloba alata Glenister \& Klapper. Baliński, p. 75, pl. 2, fig. 5 [only].

1981a Ancyrodella rotundiloba alata Glenister \& Klapper.Perri \& Spalletta, pp. 293, 294, pl. 2, figs 1-3.

1981 Ancyrodella rotundiloba alata Glenister \& Klapper.Huddle, pp. b20, b21, pl. 2, figs 1-19 [only].

1982 Ancyrodella rotundiloba alata Glenister \& Klapper. Bultynck, p. 57, pl. 2, figs 4-8 [fig. $10=$ ? A. sp.].

1983 Ancyrodella rotundiloba alata, typical form. - Bultynck, p. 165, figs $1.39,1.40$ [reillustration of figs 5 and 8 of 1982 paper, 1.38 = fig. 10 of 1982 paper].

1985 Ancyrodella alata Glenister \& Klapper, early form. - Klapper, pp. 27, 28, pl. 4, figs 1-4, 7, 8 [only], pl. 5, figs 11,12 [only].

1985 Ancyrodella alata Glenister \& Klapper, late form. - Klapper, pp. 27, 28, pl. 6, figs 1-4 [only], pl. 7, figs 1-11.

1986 Ancyrodella rotundiloba alata Glenister \& Klapper. - Ji et al., p. 97, pl. 1, figs 1, 2.

1987 Ancyrodella alata Glenister \& Klapper. - Fuchs, pl. 3, fig. 3 [only].

1989 Ancyrodella alata Glenister \& Klapper. - Sandberg, Ziegler \& Bultynck, p. 226, pl. 4, figs 10, 11.

1989b Ancyrodella rotundiloba rotundiloba Glenister \& Klapper [sic, probably a typographical error as $A$. $r$. alata was meant, see Ji \& Ziegler 1993, p. 51 and Ji 1989b, p. 306, sample YT-16]. - Ji, p. 316, pl. 3, figs $10-13$.

1991 Ancyrodella alata Glenister \& Klapper late form sensu Klapper (1985). - Uyeno, p. 158, pl. 4, figs 4-6.

1992 Ancyrodella alata Glenister \& Klapper. - Yatskov \& Kuz'min, p. 89, pl. 2, fig. 6 [only].

1993 Ancyrodella alata Glenister \& Klapper. - Racki \& Bultynck, pl. 9, figs 1, 2 [only].

1993 Ancyrodella alata Glenister \& Klapper. - Ji \& Ziegler, p. 51, pl. 1, figs 1-3.

2001 Ancyrodella alata Glenister \& Klapper. - Savage \& Yudina, pp. 287, 288, pl. 2, figs 5-7 [only].

2001 Ancyrodella cf. A. alata Glenister \& Klapper. - Savage \& Yudina, p. 288, pl. 2, figs 8-10 [only].

2003 Ancyrodella alata Glenister \& Klapper. - Over et al., pl. 1, figs 16, 17.

2007 Ancyrodella alata Glenister \& Klapper late form of Klapper 1989. - Gouwy et al., p. 388, fig. 15j [only].

2007 Ancyrodella alata. - Over, p. 1202, figs 11.14-11.17.

2008 Ancyrodella alata Glenister \& Klapper. - Ovnatanova \& Kononova, pp. 1079, 1080, pl. 26, figs 4, 5.

2009 Ancyrodella alata Glenister \& Klapper. - Li et al., p. 533, pl. 1, figs 1, 2.

2009 Ancyrodella rotundiloba (Bryant). - Li et al., p. 530, pl. 1, figs 8, 9 .

2016 Ancyrodella alata Glenister \& Klapper. - Gatovsky et al., p. 66, pl. 1, fig. 10.

2016 Ancyrodella alata Glenister \& Klapper. - Klapper \& Kirchgasser, p. 552, figs 7.1, 7.2, 7.6, 7.7, 7.11, 7.12. 
2017 Ancyrodella alata Glenister \& Klapper. - Ovnatanova et al., p. 1045, pl. 10, fig. 7; pl. 11, fig. 9; pl. 15, figs 2-5; pl. 16, fig. 3; pl. 17, figs 1-5; pl. 22, figs 6, 7; pl. 29, fig. 7; pl. 31, fig. 2 [only]; pl. 8, fig. 11[?]; pl. 23, fig. 9[?]; pl. 31, fig. 3 [=? A. africana $]$.

2020 Ancyrodella alata Glenister \& Klapper. - Kirchgasser in Kirchgasser et al., p. 210, fig. 6f, g [only].

Diagnosis. - Ancyrodella alata has the inner lobe directed anteriorly and the outer lobe laterally or slightly to the posterior. Well-developed secondary keels are under both lobes; the outer lobe may have an accessory keel directed anteriorly in some morphotypes.

Remarks. - Ancyrodella alata is closely related to A. pramosica but they differ in the platform outline of the $\mathrm{Pa}$ elements. The inner lobe of $A$. pramosica is generally both slenderer and more strongly directed to the anterior. The secondary keels of $A$. alata are in most instances not as extensive as in A. pramosica, in which they extend at least to the crimp. But some specimens of $A$. alata have equally extensive secondary keels.

Huddle (1981, pl. 2, figs 1-19) showed the range of variation in his New York Frasnian material of $A$. alata, including a morphotype with an accessory keel directed anteriorly on the outer lobe. Klapper (1985, pl. 7, figs 1,2$)$ illustrated one such specimen. Ji \& Ziegler (1993, p. 52) proposed a new species, A. huddlei, for this morphotype, based on Huddle's (1981, pl. 2, figs 7-10, 12-21) specimens, with the holotype in figs 12-14. But Ji \& Ziegler's (1993, pl. 1, fig. 10) one photographed specimen is shown only in upper view and has a quite different outline from Huddle's specimens assigned to their new species. Ji \& Ziegler's cited specimen has the characteristic outline of $A$. alata, except for the strong inner curvature of the posterior carina. The stratigraphic source of the two specimens in the drawings of $\mathrm{Ji}$ \& Ziegler (1993, text-figs 8.13, 8.14) is not given. Ancyrodella huddlei is regarded herein as an intraspecific variant of $A$. alata.

The multielement reconstruction of Ancyrodella alata (Klapper \& Philip 1972, pl. 2, figs 6-13) illustrates 6 elements, lacking only the Sd element, presumably due to lack of preservation.

\section{Ancyrodella pramosica Perri \& Spalletta, 1981}

1966 Ancyrodella rotundiloba alata n. subsp.; Glenister \& Klapper, pp. 799, 800, pl. 86, figs 3, 4 [only].

1966 Ancyrodella rotundiloba (Bryant) n. subsp.; Krebs \& Ziegler, p. 736, pl. 1, figs 6, 7 [only].

1968 Ancyrodella rotundiloba alata Glenister \& Klapper. Pollock, p. 424, pl. 61, figs 2, 3.
1971 Ancyrodella rotundiloba alata Glenister \& Klapper. Szulczewski, pp. 15, 16, pl. 1, figs 1, 2.

1976 Ancyrodella sp. nov. A. - Druce, p. 67, pl. 1, fig. 1.

1981a Ancyrodella sp. nov. A in Druce. - Perri \& Spalletta, pp. 294, 296, pl. 2, figs 4, 5.

1981b Ancyrodella pramosica n. sp.; Perri \& Spalletta, pp. 96, 98, pl. 1, figs 1-5 [fig. $3=$ holotype, reillustration of fig. 4 of preceding paper], pl. 2, figs 1-5.

1981 Ancyrodella rotundiloba alata Glenister \& Klapper. Bultynck \& Jacobs, p. 18, pl. 10, figs 10, 11 [fig. $12=$ ?].

1985 Ancyrodella pramosica Perri \& Spalletta. - Klapper, p. 28 , pl. 7, figs $12-21$, pl. 8 , figs $1-7$, text-figs $3 \mathrm{w}-\mathrm{Z}$ [w, $\mathrm{x}$ same as pl. 7, figs 16, 17; y, z same as pl. 7, figs 12, 13].

1985 Ancyrodella alata Glenister \& Klapper, late form. Klapper, pp. 27, 28, pl. 8, fig. 8 [only].

1986 Ancyrodella alata Glenister \& Klapper. - Bultynck, p. 276, pl. 1, figs 10, 11 .

1987 Ancyrodella alata Glenister \& Klapper. - Fuchs, pl. 3, fig. 1 [only].

1989 Ancyrodella pramosica Perri \& Spalletta. - Vandelaer et al., pp. 330,331, pl. 1, fig. 5.

1993 Ancyrodella pramosica Perri \& Spaletta [sic]. - Racki \& Bultynck, pl. 9, fig. 5.

2006 Ancyrodella pramosica Perri \& Spaletta [sic]. Pisarzowska et al., p. 625, fig. 13b.

2007 Ancyrodella pramosica Perri \& Spalletta.-Gouwy et al., p. 389 , fig. $15 \mathrm{k}$.

2017 Ancyrodella pramosica Perri \& Spalletta. - Ovnatanova et al., p. 1049, pl. 10, fig. 6, pl. 29, fig. 5.

[non] 2020a Ancyrodella [as Ad.] pramosica. - Becker et al., p. 75, figs $62.24,62.25$.

? 2020 Ancyrodella [as Ad.] pramosica. - Aboussalam et al., p. 149, fig. 20.22 .

Diagnosis. - Ancyrodella pramosica has the inner lobe generally slenderer and more strongly directed to the anterior than in A. alata and has generally, though not always, more extensive secondary keels.

Remarks. - García-López (1987, pp. 57, 58) compared Ancyrodella pramosica with $A$. africana, noting the similarity of their secondary keel pattern, especially in specimens of the latter that lack an accessory keel on the outer anterior lobe. She also noted differences in the platform outline and ornament. Both species have an asymmetrical platform outline with the inner lobe projecting in an anterior direction. The anterior inner lobe in A. pramosica is more alate and is longer than in most specimens of $A$. africana.

The specimen of Aboussalam et al. (2020, fig. 20.22) is not nearly as asymmetrical as that of Pa elements of A. pramosica because the anterior inner lobe is directed 
much more laterally than anteriorly. In this respect, it more nearly resembles $A$. africana. Also, the inner lobe of the specimens of Becker et al. (2020a, figs 62.24, 62.25) projects straight laterally and thus does not match the platform outline typical of $A$. pramosica (compare with Perri \& Spalletta, 1981b, pls 1, 2).

\section{Ancyrodella nodosa Group}

This group includes $A$. gigas s.s., A. gigas sensu Ziegler (1958), A. gigas form 2 (Klapper 1989), A. hamata, A. ioides s.s., A. ioides form 1 , and $A$. nodosa.

\section{Ancyrodella gigas Youngquist, 1947 s.s.}

1947 Ancyrodella gigas n. sp.; Youngquist, pp. 96, 97, pl. 25, fig. 23 [= holotype].

1947 Polygnathus rotundiloba Bryant. - Youngquist, p. 110, pl. 26, fig. 6 .

1985 Ancyrodella gigas Youngquist. - Klapper \& Lane, p. 923, fig. 14.15 [only; reillustration of holotype].

1989 Ancyrodella gigas Youngquist form 3. - Klapper, p. 457, pl. 3, fig. 13.

1994 Ancyrodella gigas Youngquist. - Sandberg et al., p. 250, pl. 1, fig. 9 .

2006 Ancyrodella aff. nodosa Ulrich \& Bassler. - Savage et al., pp. 178, 180, fig. 5r, s.

2007 Ancyrodella gigas Youngquist form 3 of Klapper, 1989. - Gouwy et al., pp. 389, 391, fig. $15 \mathrm{~m}$ [only].

2018 Ancyrodella nodosa Ulrich \& Bassler. - Huang et al., p. 65 , fig. 4.11 .

2020b Ancyrodella [as Ad.] gigas. - Becker et al., p. 108, fig. 19.1 .

Diagnosis. - Ancyrodella gigas s.s. has nearly straight secondary carinae arranged in a narrow v-shaped pattern and well developed secondary keels projecting anteriorly.

Remarks. - The holotype of Ancyrodella gigas and the very few closely similar specimens (e.g., Sandberg et al. 1994, pl. 1, fig. 9; Huang et al. 2018, fig. 4.11) have the nearly straight secondary carinae forming a distinctive $\mathrm{V}$-shaped pattern at a narrow angle and raised above the posterior platform nodes. The angle is narrower and the carinae are straighter than in $\mathrm{Pa}$ elements of $A$. nodosa, a species that has been widely misidentified as $A$. gigas (see synonymy of $A$. nodosa). This was partly due to papers I wrote (Klapper 1985, pl. 10, figs 3-6, 9, 10, 13-16 and Klapper 1989, p. 457) in which the specimens cited in the 1985 paper were taken as exemplars of A. gigas form 1. But the so-called form 1 clearly belongs in $A$. nodosa as stated under that species. The confusion of $A$. gigas and A. nodosa also occurred before 1985 .

\section{Ancyrodella gigas Youngquist sensu Ziegler, 1958}

1957 Ancyrodella gigas Youngquist. - Müller \& Müller, p. 1091, pl. 142, fig. 1 [only].

1958 Ancyrodella gigas Youngquist. - Ziegler, pp. 41, 42, pl. 11, fig. 8 [only].

1970b Ancyrodella gigas Youngquist. - Seddon, p. 94, pl. 7, fig. 6 [only].

1978 Ancyrodella gigas Youngquist. - Orchard, p. 926, pl. 114, fig. 4.

1981a Ancyrodella gigas Youngquist. - Perri \& Spalletta, pp. 292, 293, pl. 1, fig. 4.

1989b Ancyrodella gigas Youngquist. - Ji, p. 316, pl. 3, figs $1,2,4,5$.

1998a Ancyrodella gigas Youngquist. - Spalletta \& Perri, p. 197, pl. 2.1.1, fig. 5 .

1999 Ancyrodella gigas sensu Ziegler. - Lazreq, p. 58, pl. 4, fig. 1.

2001 Ancyrodella gigas Youngquist. - Savage \& Yudina, p. 288, pl. 8, figs 7-12.

2007 Ancyrodella gigas. - Over, p. 1202, fig. 11.9 [only].

2020a Ancyrodella [as Ad.] nodosa (= gigas M1). - Becker et al., p. 81, fig. 71.15 .

Diagnosis. - In this morphotype of Ancyrodella gigas the inner and outer posterior platform margins are convex lacking distinct sinuses. The secondary keels are as in A. gigas s.s.

Remarks. - The seminal paper of Ziegler (1958) led to a different concept of Ancyrodella gigas, labeled "sensu Ziegler" by Lazreq (1999). Compared with A. gigas s.s. it lacks well developed sinuses on both the inner and outer convex margins at slightly posterior of platform midlength.

\section{Ancyrodella gigas Youngquist form 2 sensu Klapper (1989)}

Figure 3A

1985 Ancyrodella gigas Youngquist. - Klapper, p. 29, pl. 10, figs 1, 2 [only].

cf. 1985 Ancyrodella gigas Youngquist. - Klapper \& Lane, p. 923, fig. 14.14 [only].

1989 Ancyrodella gigas Youngquist form 2. - Klapper, p. 457 , pl. 3, fig. 17.

cf. 2006 Ancyrodella gigas Youngquist (form 3 sensu Klapper, 1988 (sic)). - Pisarzowska et al., p. 625, fig. 13g.

cf. 2009 Ancyrodella gigas Youngquist cf. form 2 of Klapper, 1989. - Klapper, p. 412, fig. 1.3, fig. 11.

cf. 2015 Ancyrodella gigas Youngquist form 2. - Mahboubi et al., pp. 849, 851, fig. 5a.

cf. 2020 Ancyrodella [as Ad.] gigas s. str. - Aboussalam et al., p. 149 , fig. 20.20 . 
Diagnosis. - Ancyrodella gigas form 2 has a strongly convex outer posterior platform margin uninterrupted by a sinus. Secondary keels are as in A. gigas s.s.

Remarks. - The form 2 morphotype of Ancyrodella gigas has the outer posterior platform margin formed by a convex curve without development of a sinus and an incurved posterior carina. In contrast, the holotype of $A$. gigas (reillustrated by Klapper \& Lane 1985, fig. 14.15) has well developed sinuses at slightly posterior of platform midlength and the posterior carina is sinuous rather than incurved. The morphotype here termed " $c f$. form 2" illustrated in Fig. 3B and those so noted in the synonymy list, have a similar platform outline to that of form 2 but the platform is covered with strong nodes instead of partly broken ridges and few nodes. The outer posterior platform outline anterior of the posterior tip is slightly concave in the specimen of Aboussalam et al. (2020, fig. 20.20) thus differing from others here termed " $c f$. form 2", except that of Mahboubi et al. (2015). However, the inner platform outline is essentially the same so the " $c f$. " designation is appropriate.

\section{Ancyrodella hamata Ulrich \& Bassler, 1926}

Figures 2H; 3C, D

1926 Ancyrodella hamata new species; Ulrich \& Bassler, p. 48, pl. 7, fig. 7 [ = holotype, reillustrated in Huddle 1968, pl. 13, fig. 1], text-fig. 5.10.

1926 Ancyrodella symmetrica new species; Ulrich \& Bassler, p. 49, pl. 8, fig. 1 [reillustrated in Huddle 1968, pl. 13, figs 2, 3].

1938 Ancyrodella buckeyensis n. sp.; Stauffer, p. 418, pl. 52, figs 17, 18, 23, 24 [figs 23, 24 = lectotype selected by Müller \& Müller 1957, p. 1091].

1938 Ancyrodella plena n. sp.; Stauffer, p. 418, pl. 52, figs 21, 22.

1938 Ancyrodella robusta n. sp.; Stauffer, p. 418, pl. 52, figs 28, 29.

1947 Ancyrodella lobata Branson \& Mehl. - Miller \& Youngquist, pp. 502, 503, pl. 74, figs 10-12 [specimen in fig. 12 reillustrated by Klapper \& Kirchgasser 2016, fig. 9.13].

1947 Ancyrodella magister n. sp.; Miller \& Youngquist, p. 503, pl. 74, fig. 14 [= holotype, reillustrated by Klapper \& Kirchgasser 2016, fig. 9.16].

1947 Ancyrodella subrotunda n. sp.; Miller \& Youngquist, p. 503, pl. 74, fig. 17.

1956 Ancyrodella sp. - Müller, p. 1340, pl. 145, fig. 13 [only].

1957 Ancyrodella buckeyensis Stauffer. - Müller \& Müller, p. 1091, pl. 136, fig. 5 [same specimen as preceding reference; non fig. $2=A$. sp. indet.].

1957 Ancyrodella subrotunda Miller \& Youngquist. - Müller \& Müller, p. 1092, pl. 136, fig. 6.
1958 Ancyrodella buckeyensis Stauffer. - Ziegler, p. 40, pl. 11, fig. 7.

1971 Ancyrodella buckeyensis Stauffer. - Szulczewski, p. 11, pl. 2, fig. 1 .

1976 Ancyrodella buckeyensis Stauffer. - Druce, pp. 53-55, pl.1, figs 2, 4; pl. 2, figs 2, 4, 5 [only].

1976 Ancyrodella nodosa Ulrich \& Bassler. - Druce, pp. 61, 62, pl. 8, fig. 1 [only].

1978 Ancyrodella nodosa Ulrich \& Bassler. - Orchard, p. 928 , pl. 114, fig. 3 .

1981a Ancyrodella buckeyensis Stauffer. - Perri \& Spalletta, p. 292, pl. 1, fig. 1 .

1985 Ancyrodella nodosa Ulrich \& Bassler. - Olivieri, p. 282, pl. 3, figs 3,4 .

1987 Ancyrodella nodosa Ulrich \& Bassler. - Fuchs, pl. 3, figs 5, 7, ?10.

1989a Ancyrodella nodosa Ulrich \& Bassler. - Ji, p. 294, pl. 1, figs 27, 28.

1989b Ancyrodella nodosa Ulrich \& Bassler. - Ji, p. 316, pl. 3 , fig. 6 .

1992 Ancyrodella nodosa Ulrich \& Bassler. - Uyeno, p. 72, pl. 16, figs 1-5 [only].

1992 Ancyrodella nodosa Ulrich \& Bassler. - Savage, p. 280, figs 4.13, 4.14 .

1992 Ancyrodella nodosa Ulrich \& Bassler. - Helsen \& Bultynck, p. 152, pl. 1, fig. 5.

1997 Ancyrodella buckeyensis Stauffer.-Over, pp. 172, 174, figs 11.1-11.9 [fig. 11.7 = reillustration of lectotype, synonymy].

1999 Ancyrodella nodosa Ulrich \& Bassler. - Lazreq, pp. 58, 60, pl. 4, figs 7, 8 .

2000 Ancyrodella buckeyensis Stauffer. - Over \& Rhodes, p. 109 , fig. 6.1 .

2004 Ancyrodella buckeyensis Stauffer. - Klapper et al., p. 383, fig. 5.5 [synonymy].

2006 Ancyrodella nodosa Ulrich \& Bassler. - Savage et al., p. 178, fig. 5v-x [only].

2007a Ancyrodella [as An.] buckeyensis Stauffer. - Klapper, tables 1-3.

2007 Ancyrodella buckeyensis Stauffer. - Over, pp. 1201, 1202, figs 11.1-11.3.

2009 Ancyrodella buckeyensis Stauffer. - Navas-Parejo et al., p. 115, figs 3.1, 3.2.

2013 Ancyrodella buckeyensis Stauffer. - Savage, p. 7, figs 5.1, 5.2, 5.26-5.28, 6.26-6.29.

2016 Ancyrodella hamata Ulrich \& Bassler. - Klapper \& Kirchgasser, pp. 537, 539, figs 9.13-9.18.

2019 Ancyrodella hamata Ulrich \& Bassler. - Savage, p. 484, figs 7.20, 7.21 [same specimen as Savage 2013, figs 6.26, 6.27], 8.22-8.24 [same specimen as op. cit., figs 5.1, 5.2], 9.27-9.32, 11.18-11.21, 12.2112.23 [same specimen as op. cit., figs 5.26-5.28].

[non] 2020a Ancyrodella [as Ad.] hamata (= gigas M2). - Becker et al., p. 75, fig. 62.23 [=? A. sp. indet.]. 
Diagnosis. - Ancyrodella hamata, with extremely rare exception, lacks posterior rows of nodes parallel to the carina. Secondary keels project anteriorly.

Remarks. - Ancyrodella hamata was an unused name after its initial proposal in 1926, with the exception of the paper by Müller \& Müller 1957, who used it for the closely related species $A$. nodosa, until its revival by Klapper \& Kirchgasser (2016, pp. 537, 539). Huddle (1968, p. 6) and Klapper \& Lane (1985, p. 925) had treated A. hamata as a junior synonym of $A$. nodosa, which were published in the same paper. But the two can be distinguished although there is some intergradation, especially in the platform outline (see Klapper \& Kirchgasser 2016, fig. 9). Commonly the outlines are distinct, however. The specimen in fig. 9.14 of that paper has the posterior rows of nodes parallel to the carina, the distinguishing characteristic of $A$. nodosa that is almost always absent in A. hamata. But this specimen has the characteristic outline of A. hamata so it is identified as such. It should not be necessary to emphasize that because there are some transitional specimens need not mean that the two taxa are the same species.

The Pa element identified as $A$. hamata by Becker et al. (2020a, fig. 62.23) has an extremely different outline from that characteristic of $A$. hamata. Furthermore, the platform outline of their Morocco specimen is not at all similar to A. gigas form 2 of Klapper (1989), nor is that morphotype similar to A. hamata.

\section{Ancyrodella ioides Ziegler, 1958 s.s.}

Figure 2B-D

1958 Ancyrodella ioides n. sp.; Ziegler, pp. 42, 43, pl. 11, figs 2, 3 [only; fig. 2 = holotype].

1970 Ancyrodella ioides Ziegler. - Khalymbadzha \& Chernysheva, pp. 97, 102, pl. 2, figs 18, 19.

1973 Ancyrodella ioides Ziegler. - Ziegler, pp. 23, 24, Ancyro pl. 1, fig. 6 [only; reillustration of holotype].

1982 Ancyrodella ioides Ziegler. - Mouravieff, p. 113, pl. 2, fig. 9.

1987 Ancyrodella ioides Ziegler. - Fuchs, pl. 3, fig. 6.

1989a Ancyrodella ioides Ziegler. - Ji, p. 294, pl. 1, figs 23, 24 [only].

1992 Ancyrodella ioides Ziegler. - Helsen \& Bultynck, p. 152 , pl. 1, fig. 3 .

1999 Ancyrodella ioides Ziegler. - Lazreq, p. 58, pl. 4, fig. 2.

2013 Ancyrodella ioides Ziegler. - Savage, p. 9, figs 7.15, 7.16 [only].

2016 Ancyrodella ioides Ziegler. - Gatovsky et al., p. 66, pl. 1, fig. 8 .

2019 Ancyrodella ioides Ziegler. - Savage, p. 484, figs 5.23, 5.24 [only; same specimen as Savage 2013, figs 7.15, 7.16]. 2020b Ancyrodella [as Ad.] ioides. - Becker et al., p. 106, fig. 18.13 .

Diagnosis. - Ancyrodella ioides s.s. completely lacks a platform posterior of the secondary carinae.

Remarks. - The Pa element of Ancyrodella ioides s.s. is characterized by a posterior carina and secondary carinae but otherwise lacks platform development. The blade and carina are gently incurved and the outer secondary carina in distinctly and strongly reclined posteriorly.

\section{Ancyrodella ioides form 1 new morphotype}

Figure $2 \mathrm{E}-\mathrm{G}$

1958 Ancyrodella ioides n. sp.; Ziegler, pp. 42, 43, pl. 11, fig. 4 [only].

1966 Ancyrodella nodosa Ulrich \& Bassler. - Glenister \& Klapper, pp. 798, 799, pl. 86, figs 11, 12 [only].

1970 Ancyrodella nodosa Ulrich \& Bassler. - Khalymbadzha \& Chernysheva, pp. 96, 97, pl. 2, figs 12, 13 [only].

1970a Ancyrodella ioides Ziegler. - Seddon, p. 753, pl. 16, fig. 6 .

1970a Ancyrodella nodosa Ulrich \& Bassler. - Seddon, p. 753, pl. 16, fig. 5 .

1971 Ancyrodella ioides Ziegler. - Szulczewski, pp. 12, 13, pl. 5, fig. 1.

1973 Ancyrodella ioides Ziegler. - Ziegler, pp. 23, 24, Ancyro pl. 1, fig. 5 [only].

1976 Ancyrodella ioides Ziegler. - Druce, pp. 58, 59, pl. 4, figs 3, 4 [only; figs 1, 2 are too small for confident identification].

1981a Ancyrodella ioides Ziegler. - Perri \& Spalletta, p. 293, pl. 1, fig. 2.

1982 Ancyrodella nodosa Ulrich \& Bassler. - Mouravieff, pp. 113, 114, pl. 2, fig. 8; pl. 3, fig. 8 [only].

1983 Ancyrodella nodosa Ulrich \& Bassler. - Boogaard, p. 3, pl. 1, fig. 5 [only].

1989 Ancyrodella nodosa Ulrich \& Bassler. - Orchard, p. 42, pl. 1, fig. 5 .

1989a Ancyrodella ioides Ziegler. - Ji, p. 294, pl. 1, figs 25, 26 [only].

1989b Ancyrodella ioides Ziegler. - Ji, p. 316, pl. 3, fig. 7.

1993 Ancyrodella ioides Ziegler. - Ji \& Ziegler, pp. 52, 53, pl. 2, figs 1-3.

1998 Ancyrodella nodosa Ulrich \& Bassler. - Bultynck et al., p. 66, pl. 6, fig. 4.

2007a Ancyrodella [as An.] buckeyensis transitional with [as tr. w.] An. ioides. - Klapper, tabs 2a, 2b, 3.

2008 Ancyrodella nodosa Ulrich \& Bassler. - Ovnatanova \& Kononova, pp. 1080, 1081, 1155, pl. 26, figs 11-13 [only].

2013 Ancyrodella ioides Ziegler. - Savage, p. 9, figs 5.23-5.25 [only]. 


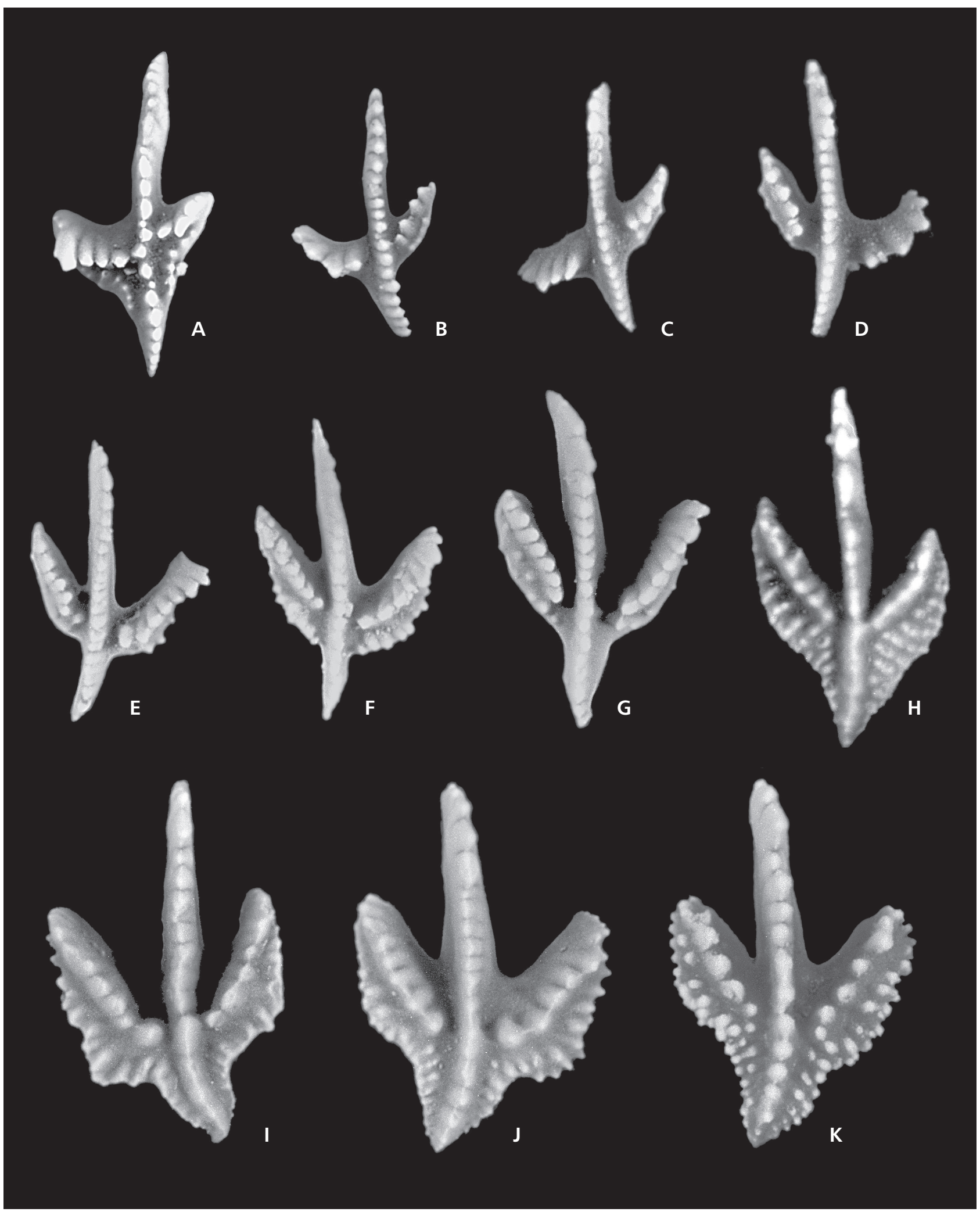

Figure 2. All photographs are upper views, magnifications $\times 40$. A - homeomorph of Ancyrodella ioides Ziegler 1958 s.s., F54970, HS 364-70, FZ 13a. • B-D - Ancyrodella ioides Ziegler 1958 s.s., F51422 [previously illustrated in Klapper 2009, fig. 1.3.3], F54971-54972, all from HS 364-34, FZ 12. E-G - Ancyrodella ioides form 1 new morphotype, F54973-54975, HS 364-43, 45, 43, FZ 12. • H - Ancyrodella hamata Ulrich \& Bassler 1926, F54976, HS 364-71, FZ 13b. • I, J, K - Ancyrodella nodosa Ulrich \& Bassler 1926; I, J - F54977-54978, HS 364-12, FZ 11; K - F54979, HS 364-18, FZ 11 [This specimen is identified with some question]. 
2013 Ancyrodella ioides Ziegler. - Tagarieva, p. 308, fig. $7 \mathrm{~s}$.

2013 Ancyrodella ioides Ziegler. - Bahrami et al., p. 380, figs $7 \mathrm{p}$, q [fig. $7 \mathrm{r}=$ ?].

2019 Ancyrodella ioides Ziegler. - Savage, p. 484, figs 6.19-6.21, 12.18-12.20 [same specimen as Savage 2013, figs 5.23-5.25] [only].

Diagnosis. - The form 1 morphotype of Ancyrodella ioides s.s. has an extremely narrow platform posterior of the secondary carinae.

Remarks. - The new morphotype designated here as Ancyrodella ioides form 1 has heretofore always been included within $A$. ioides without qualification, as seen in the above synonymy. However, it differs consistently by the development of an extremely narrow platform posterior of the secondary carinae. The transitional nature of the two morphotypes is evidenced by the specimen illustrated by Savage (2019, fig. 12.18), which has an incipiently developed outer platform posterior of the secondary carina that is distinctly reclined as in A. ioides s.s. The Canning Basin specimens of form 1 such as those in Fig. 2E and 2G also have an incipiently developed outer platform although the secondary carina is only slightly reclined. The difference between $A$. ioides s.s and form 1 is small indicating they should be considered as morphotypes within the one species. The single unique specimen from Horse Spring in FZ13a (Fig. 2A), termed as a homeomorph of $A$. ioides s.s, has a triangular platform posterior of the secondary carinae with small rows of nodes adjacent to and parallel to the posterior carina.

\section{Ancyrodella nodosa Ulrich \& Bassler, 1926}

Figures 1C-F, 2I-K

1926 Ancyrodella nodosa new species; Ulrich \& Bassler, p. 48, pl. 1, figs 10-13 [fig. $10=$ lectotype selected by Ziegler 1958, p. 44], text-figs 5.8, 5.9.

1956 Ancyrodella sp. - Müller, p. 1340, pl. 145, figs 12, 14 [only].

1957 Ancyrodella hamata Ulrich \& Bassler. - Müller \& Müller, pp. 1091, 1092, pl. 136, fig. 4.

1958 Ancyrodella nodosa Ulrich \& Bassler. - Ziegler, p. 44, pl. 11, fig. 1.

1958 Ancyrodella gigas Youngquist. - Ziegler, pp. 41, 42, pl. 11, fig. 10 [only; fig. $17=$ ?, shown in an oblique lateral view].

1959 Ancyrodella buckeyensis Stauffer, 1938. - Krebs, p. 384, pl. 1, fig. 6 .

1966 Ancyrodella gigas Youngquist. - Anderson, p. 403, pl. 48, figs 10, 14.

1966 Ancyrodella nodosa Ulrich \& Bassler. - Glenister \&
Klapper, pp. 798, 799, pl. 86, figs 5, 6, 9, 10 [only; figs 7, $8=$ transitional morphotype between $A$. nodosa and $A$. hamata].

1968 Ancyrodella nodosa Ulrich \& Bassler. - Huddle, pp. 6, 7, pl. 13, figs 7-10 [only; reillustrations of Ulrich \& Bassler, pl. 1, figs 10, 11, 12, 13, respectively].

1970 Ancyrodella nodosa Ulrich \& Bassler. - Khalymbadzha \& Chernysheva, pp. 96, 97, pl. 2, figs 10, 11 [only].

1970b Ancyrodella nodosa Ulrich \& Bassler. - Seddon, p. 94, pl. 7, fig. 18.

1970b Ancyrodella gigas Youngquist. - Seddon, p. 94, pl. 7 , fig. 7 [only].

1971 Ancyrodella gigas Youngquist. - Szulczewski, p. 12, pl. 4, fig. 1 [only].

1971 Ancyrodella nodosa Ulrich \& Bassler. - Szulczewski, pp. 14, 15, pl. 2, fig. 4; pl. 5, figs 2-4 [only].

1971 Ancyrodella rugosa Branson \& Mehl. - Szulczewski, p. 16, pl. 2, fig. 5 .

1971 Ancyrodella sp. A; Szulczewski, p. 17, pl. 5, fig. 6.

1976 Ancyrodella nodosa Ulrich \& Bassler. - Druce, pp. 61, 62, pl. 7, figs 1-3; pl. 8, figs 2, 3 [only].

1976 Ancyrodella gigas Youngquist. - Druce, pp. 57, 58, pl. 3, figs 1, 2 [only].

1981a Ancyrodella lobata Branson \& Mehl. - Perri \& Spalletta, p. 293, pl.1, fig. 5 [only].

1981 Ancyrodella gigas Youngquist. - Bultynck \& Jacobs, p. 24, pl. 9, figs 9-11.

1983 Ancyrodella nodosa Ulrich \& Bassler. - Boogaard, p. 3 , pl. 1, fig. 3 [only].

1985 Ancyrodella gigas Youngquist. - Klapper, p. 29, figs 3ee-ff [non fig. gg = A. gigas holotype]; pl. 10, figs 9, 10, 13-16 [only; figs 9, $10=$ same specimen as figs 3ee-ff; non figs 3-6=A. devonica $]$.

1985 Ancyrodella nodosa Ulrich \& Bassler. - Klapper \& Lane, pp. 925, 927, figs 14.6, 14.7, 14.10, 14.11.

1989 Ancyrodella gigas Youngquist form 1. - Klapper, p. 457.

1989 Ancyrodella gigas Youngquist alpha morphotype. Vandelaer et al., pp. 329, 330, pl. 2, fig. 5.

1989 Ancyrodella gigas Youngquist beta morphotype. Vandelaer et al., pp. 329, 330, pl. 2, fig. 6 [only].

1992 Ancyrodella nodosa Ulrich \& Bassler. - Savage, p. 280, figs 4.13, 4.14 .

1992 Ancyrodella nodosa Ulrich \& Bassler. - Helsen \& Bultynck, p. 152, pl. 1, fig. 5.

1993 Ancyrodella nodosa Ulrich \& Bassler. - Ji \& Ziegler, p. 53, pl. 2, fig. 11 [fig. $12=$ ?].

2000 Ancyrodella gigas Youngquist. - Gouwy \& Bultynck, p. 40, pl. 1, figs 9, 10 [only; the specimen in figs 11,12 is not well enough preserved for confident identification].

2002 Ancyrodella nodosa Ulrich \& Bassler. - Dzik, p. 590, fig. 25f, 25h [only]. 
2003 Ancyrodella gigas Youngquist form 1 of Klapper (1989). - Over et al., p. 222, pl. 1, fig. 5.

2006 Ancyrodella nodosa Ulrich \& Bassler. - Savage et al., p. 178, fig. 6g, h [only].

2006 Ancyrodella gigas Youngquist (form 1 sensu Klapper, 1988 (sic)). - Pisarzowska et al., p. 625, fig. 13d, e.

2007 Ancyrodella gigas Youngquist form 1 of Klapper, 1989. - Gouwy et al., pp. 389, 391, fig. 15n [only].

2007 Ancyrodella nodosa Ulrich \& Bassler. - Over, pp. 1202, 1206, fig. 11.8.

2007 Ancyrodella gigas. - Over, p. 1202, figs 11.10, 11.12, 11.13 [only].

2008 Ancyrodella gigas Youngquist. - Ovnatanova \& Kononova, pp. 1080, 1155, pl. 26, figs 6, 8.

2008 Ancyrodella nodosa Ulrich \& Bassler. - Ovnatanova \& Kononova, pp. 1080, 1081, 1155, pl. 26, fig. 15 [only; figs 14, $16=$ juveniles that are too small for confident identification].

2008 Ancyrodella rugosa Branson \& Mehl. - Ovnatanova \& Kononova, pp. 1081, 1082, pl. 26, fig. 7.

2013 Ancyrodella gigas Youngquist. - Tagarieva, p. 308, fig. 7 o.

2013 Ancyrodella nodosa s.s. - Over et al., p. 13, fig. 7a.3.

2015 Ancyrodella gigas Youngquist Morphotype 1: Klapper (1985) [sic]. - Becker \& Aboussalam, p. 118, pl. aii-2, figs 2, 3.

2016 Ancyrodella nodosa Ulrich \& Bassler. - Gatovsky et al., p. 66, pl. 1, fig. 4.

2016 Ancyrodella nodosa Ulrich \& Bassler. - Klapper \& Kirchgasser, pp. 537, 538, figs 9.1-9.12 [fig. $9.4=$ reillustration of lectotype; additional synonymy].

2017 Ancyrodella nodosa Ulrich \& Bassler. - Ovnatanova et al., pp. 1046, 1049, pl. 41, figs 3, 5 [only].

2017 Ancyrodella rotundiloba (Bryant). - Königshof et al., p. 525 , fig. 4.2 .

2018 Ancyrodella nodosa Ulrich \& Bassler. - Dzik et al., p. 331, fig. 31 (photo reversed), $3 \mathrm{~m}$ [only; reillustrations of Dzik 2002, fig. 25f, 25h].

2019 Ancyrodella rugosa Branson \& Mehl. - Nazarova et al., p. 91, pl. 3, fig. 15.

2020b Ancyrodella [as Ad.] nodosa. - Becker et al., p. 106, fig. 18.1.

2020 Ancyrodella [as Ad.] nodosa (= gigas M1). - Aboussalam et al., p. 149, fig. 20.8 .

Diagnosis. - Ancyrodella nodosa has posterior rows of nodes closely parallel to, and on both sides of the carina. Secondary keels project anteriorly.

Remarks. - As stated in the diagnosis of A. nodosa (Klapper \& Kirchgasser 2016, p. 537): "Each secondary carina meets or comes close to a slightly curved row of nodes that parallels the posterior carina and is separated from it by an adcarinal trough." In their figures 9.1, 9.3 (paralectotype), 9.4 (lectotype), 9.7, 9.9, 9.10 the specimens have the meeting of the secondary carinae and the posterior node-rows, but there is a conspicuous onedenticle gap on the inner (fig. 9.11) or outer side (fig. 9.12). This variable gap or non-gap is a characteristic feature of A. nodosa Pa elements and the posterior node-rows may be weakly developed in some specimens that are nevertheless included here within the intraspecific variation of the species (e.g., Müller 1956, pl. 145, fig. 14; Müller \& Müller 1957, pl. 136, fig. 4, outer but not inner side; Ziegler 1958, pl. 11, fig. 10a; Glenister \& Klapper 1966, pl. 86, fig. 6, inner side node-row is weak; Savage et al. 2006, fig. $6 \mathrm{~g}$, outer posterior node-row well developed but lacks node-row on inner side). The specimens in Fig. 2I and $\mathrm{J}$ also have only weakly developed posterior node rows, but do have the characteristic platform outline of A. nodosa.

Based on the evidence of the types of Ulrich \& Bassler's species (as reillustrated by Huddle 1968, Klapper \& Kirchgasser 2016), as well as the many other specimens now placed in $A$. nodosa, A. gigas Youngquist form 1 proposed by Klapper (1989, p. 457) is identical with A. nodosa. This is because most of the specimens originally given in that paper as examples of form 1 are the same as $A$. nodosa (according to the synonymy above; note that the specimens cited in Klapper 1985, pl. 10, figs 3-6 are not included herein in $A$. nodosa, but rather in $A$. devonica).

\section{Ancyrodella curvata Group}

This group includes $A$. curvata s.s., A. curvata early form, and $A$. lobata.

\section{Ancyrodella curvata (Branson \& Mehl, 1934) s.s.}

1934 Ancyrognathus curvata new species; Branson \& Mehl, p. 241, pl. 19, figs 6, 11 [= lectotype selected by Ziegler 1958, p. 41].

1957 Ancyropenta asteroideus (Stauffer). - Müller \& Müller, p. 1093, pl. 136, figs 7, 8.

1962 Ancyrodella curvata (Branson \& Mehl). - Ethington \& Furnish, pp. 1261, 1262, pl. 172, figs 12-20.

1966 Ancyrodella curvata (Branson \& Mehl). - Anderson, p. 403, pl. 48, figs 6, 9, 11, 13 [only].

1966 Ancyrodella curvata (Branson \& Mehl). - Glenister \& Klapper, p. 798, pl. 86, figs 13-15.

1970b Ancyrodella curvata (Branson \& Mehl). - Seddon, p. 94, pl. 7, figs 12, 13.

1971 Ancyrodella curvata (Branson \& Mehl). - Szulczewski, pp. 11, 12, pl. 3, fig. 5, pl. 4, figs 4,5 .

1976 Ancyrodella curvata (Branson \& Mehl). - Druce, pp. 55-57, pl. 1, fig. 3.

1978 Ancyrodella curvata (Branson \& Mehl). - Orchard, 
p. 926 , pl. 114, figs 2,10 [figs $8,9,20=$ indet. juveniles].

1981 Ancyrodella curvata (Branson \& Mehl). - Bultynck \& Hollard, p. 38, pl. 10, fig. 12.

1981 Ancyrodella lobata Branson \& Mehl. - Bultynck \& Jacobs, p. 24, pl. 9, fig. 12 [only].

1982 Ancyrodella curvata (Branson \& Mehl). - Mouravieff, p. 114, pl. 3, figs 10, 11 [only].

1984 Ancyrodella curvata (Branson \& Mehl). - Matthews \& Riddolls, p. 34, pl. 6, figs 1, 2, 7.

1985 Ancyrodella curvata (Branson \& Mehl). - Olivieri, p. 280, pl. 3, fig. 6 .

1986 Ancyrodella curvata (Branson \& Mehl). - GarcíaLópez, p. 454, pl. 3, figs 17-19.

1987 Ancyrodella curvata (Branson \& Mehl). - GarcíaLópez, pp. 59, 60, pl. 3, figs 11-13, text-fig. 11.

1987 Ancyrodella curvata (Branson \& Mehl). - Fuchs, pl. 3 , fig. 9 [only]; pl. 16, fig. 13.

1989 Ancyrodella curvata (Branson \& Mehl) late form. Klapper, p. 457, pl. 3, fig. 20.

1992 Ancyrodella curvata (Branson \& Mehl). - Sandberg et al., p. 74, pl. 4, fig. 2 [only; termed as late morphotype].

1992 Ancyrodella curvata (Branson \& Mehl). - Helsen \& Bultynck, p. 152, pl. 1, fig. 1.

1993 Ancyrodella curvata (Branson \& Mehl). - Ji \& Ziegler, pp. 51, 52, pl. 2, fig. 4 [only].

1995 Ancyrodella curvata (Branson \& Mehl). - Schülke, p. 65 , pl. 14, figs 12, 13.

1997 Ancyrodella curvata (Branson \& Mehl). - Schülke, pp. 42-44, pl. 1, fig. 10; pl. 2, figs 1-8, 10-20 [multielement reconstruction].

1997 Ancyrodella curvata (Branson \& Mehl) (late form). - Over, p. 174, figs 11.10-11.14.

1998 Ancyrodella curvata (Branson \& Mehl) late form. Bultynck et al., pp. 55, 66, pl. 6, figs 1, 2.

1998 Ancyrodella curvata (Branson \& Mehl) latest form. Bultynck et al., pp. 55, 65, 66, pl. 5, figs 8-10; pl. 6, fig. 3.

1998b Ancyrodella curvata (Branson \& Mehl). - Spalletta \& Perri, p. 205, pl. 2.2.1, fig. 1.

1999 Ancyrodella curvata (Branson \& Mehl). - Lazreq, p. 58, pl. 4, figs 3,4 .

1999 Ancyrodella curvata (Branson \& Mehl). - Schülke, p. 64, pl. 11, figs 20-23 (partial multielement reconstruction).

2000 Ancyrodella curvata (Branson \& Mehl) late form. Gouwy \& Bultynck, pp. 40, 49, pl. 2, figs 1-3.

2000 Ancyrodella curvata (Branson \& Mehl) latest form. Gouwy \& Bultynck, p. 40, 49, pl. 2, fig. 4.

2002 Ancyrodella lobata Branson \& Mehl. - Dzik, p. 590, fig. 27d [only].

2002 Ancyrodella curvata Branson \& Mehl [sic]. - Dzik, p. 590 , fig. $27 \mathrm{~g}$, h [only].
2006 Ancyrodella curvata Branson \& Mehl [sic]. - Savage et al., p. 178, fig. 5n-q.

2007 Ancyrodella curvata (Branson \& Mehl) late form of Klapper, 1989. - Gouwy et al., p. 389, fig. 15t.

2007 Ancyrodella curvata (Branson \& Mehl) late form. Over, p. 1202, figs 11.4, 11.7.

2013 Ancyrodella curvata (Branson \& Mehl). - Tagarieva, p. 308 , fig. $7 \mathrm{~m}$, n.

2013 Ancyrodella curvata (Branson \& Mehl). - Bahrami et al., pp. 382, 384, fig. 7n, t.

2018 Ancyrodella curvata Branson \& Mehl [sic]. - Dzik et al., p. 331, fig. 3c, d [only; c = reillustration of Dzik 2002, fig. 27g; d (photo reversed) = reillustration of Dzik 2002, fig. 27h].

2020a Ancyrodella [as Ad.] curvata late morph. - Becker et al., p. 81, fig. 71.20.

2020b Ancyrodella [as Ad.] curvata late form. - Becker et al., pp. 106, 108, figs 18.20, 19.12.

Diagnosis. - Ancyrodella curvata s.s. has a well defined outer posterior lobe formed by distinct sinuses on both the anterior and posterior sides. This lobe has a strong accessory carina.

Remarks. - Ancyrodella curvata s.s. (= A. curvata late form of Klapper 1989, both late and latest forms of Bultynck et al. 1998 and Gouwy \& Bultynck 2000) differs from the early form of Klapper (1989) by the presence of a distinct outer posterior lobe that is demarcated by sinuses on either side of the lobe. Compare for example, the early form (Klapper 1989, pl. 3, figs 18, 19) with the late form (op. cit., fig. 20). Both morphs have a distinct accessory carina on the outer side posterior of midlength. There is a transition, however, between the two morphs as is well illustrated by the three specimens in Sandberg et al. (1992, pl. 4, fig. $1=$ A. curvata early morphotype, fig. $2=$ A. curvata s.s. or late morphotype, and fig. $3=$ intermediate morphotype in their designations). The intermediate morphotype has only a slight incipient sinus developed between the tips of the outer accessory carina and the posterior carina. The intermediate morphotype seems to be relatively infrequent (and is included herein within the A. curvata early form). The existence of the transition justifies treating the two as morphotypes of the same species.

Ethington \& Furnish (1962), Over (1997), and Schülke (1997) have illustrated ontogenetic series for the A. curvata s.s. Pa (P1) element. Furthermore, Schülke (1997, pl. 2, figs 1-8, 10-20) proposed a multielement reconstruction for this species lacking only the Sd element.

Branson \& Mehl (1934) originally included their new species curvata within Ancyrognathus so the authors' names must be in parentheses as it subsequently became a changed genus combination. 


\section{Ancyrodella curvata (Branson \& Mehl, 1934) early form}

1958 Ancyrodella curvata (Branson \& Mehl). - Ziegler, pp. 40, 41, pl. 11, fig. 5 .

1966 Ancyrodella curvata (Branson \& Mehl). - Anderson, p. 403, pl. 48, figs 2, 4 [only].

1970a Ancyrodella curvata (Branson \& Mehl). - Seddon, p. 753 , pl. 16, figs 3,4 .

1970b Ancyrodella lobata Branson \& Mehl. - Seddon, p. 94, pl. 7, figs 15, 17 [only].

1971 Ancyrodella lobata Branson \& Mehl. - Szulczewski, pp. 13, 14, pl. 3, fig. 3 [only].

1976 Ancyrodella lobata Branson \& Mehl. - Druce, pp. 59-61, pl. 5, fig. 1 [only].

1981a Ancyrodella curvata (Branson \& Mehl). - Perri \& Spalletta, p. 292, pl. 1, fig. 3.

1982 Ancyrodella curvata (Branson \& Mehl). - Mouravieff, p. 113, pl. 2, figs 10-13 [only].

1987 Ancyrodella curvata (Branson \& Mehl). - Fuchs, pl. 3, fig. 8 [only].

1989 Ancyrodella curvata (Branson \& Mehl) early form. Klapper, p. 457, pl. 3, figs 18, 19.

1989 Ancyrodella curvata (Branson \& Mehl). - Vandelaer et al., p. 329, pl. 3, fig. 1.

1992 Ancyrodella curvata (Branson \& Mehl). - Sandberg et al., p. 74, pl. 4, figs 1, 3 [only;1 termed as early morphotype, 3 as intermediate morphotype].

1993 Ancyrodella curvata (Branson \& Mehl). - Ji \& Ziegler, pp. 51, 52, pl. 2, fig. 5 [only].

2000 Ancyrodella curvata (Branson \& Mehl) early form. Gouwy \& Bultynck, pp. 40, 49, pl. 2, figs 5, 6 .

2000 Ancyrodella curvata (Branson \& Mehl). - Çapkinoğlu \& Gedik, p. 84, pl. 3, fig. 16.

2007 Ancyrodella curvata (Branson \& Mehl) early form of Klapper, 1989. - Gouwy et al., p. 389, fig. 15p-s.

2020a Ancyrodella [as Ad.] curvata early morph. - Becker et al., p. 81, fig. 71.19.

2020b Ancyrodella [as Ad.] curvata early form. - Becker et al., p. 106, fig. 18.12 .

Diagnosis. - Ancyrodella curvata early form lacks the well demarcated outer posterior lobe that is developed in A. curvata s.s., but shares a strong accessory carina in the same outer posterior position. The platform outline is close to trapezoidal.

Remarks. - The early form of Ancyrodella curvata has a well developed accessory carina on the outer side posterior of midlength (e.g., Klapper 1989, pl. 3, figs 18, 19; Gouwy \& Bultynck 2000, pl. 2, fig. 11). In contrast, in that same position in A. lobata, a carina is either absent or at most represented by a row of several separated nodes (e.g., Druce 1976, pl. 5, fig. 2a, pl. 6, figs 1a, 2b, 3a; Dzik 2002, fig. 27c). Both have a characteristic almost trapezoidal platform outline.

\section{Ancyrodella lobata Branson \& Mehl, 1934}

Figure 3E-I

1934 Ancyrodella lobata n. sp.; Branson \& Mehl, pp. 239, 240, pl. 19, fig. 14; pl. 21, figs 22, 23 [fig. $22=$ lectotype selected by Ziegler 1958, p. 43; fig. 22 is the upper view of the specimen on pl. 19, fig. 14].

1957 Ancyropenta longidenticulata n. sp.; Müller \& Müller, p. 1093, pl. 136, fig. 3; pl. 137, figs 1, 2 [fig. $1=$ holotype].

1958 Ancyrodella lobata Branson \& Mehl. - Ziegler, p. 43, pl. 11, figs 6, 9.

1966 Ancyrodella lobata Branson \& Mehl. - Anderson, p. 403, pl. 48, figs 15,16 .

1968 Ancyrodella lobata Branson \& Mehl. - Mound, pp. 470, 471, pl. 65, figs 7-12.

1970a Ancyrodella lobata Branson \& Mehl. - Seddon, p. 753, pl. 16, fig. 2.

1970b Ancyrodella lobata Branson \& Mehl. - Seddon, p. 94, pl. 7, figs 8-11, 14 [only; fig. 16=?].

1971 Ancyrodella lobata Branson \& Mehl. - Szulczewski, pp. 13, 14, pl. 3, figs 1, 2, 4 [only]; pl. 4, figs 2, 3.

1971 Ancyrodella gigas Youngquist. - Szulczewski, p. 12, pl. 2, fig. 3 [only].

1976 Ancyrodella lobata Branson \& Mehl. - Druce, pp. 59-61, pl. 5, fig. 2 [only]; pl. 6, figs 1-3.

1976 Ancyrodella buckeyensis Stauffer. - Druce, pp. 53-55, pl. 2, fig. 3 [only].

1976 Ancyrodella gigas Youngquist. - Druce, pp. 57, 58, pl. 3 , fig. 3 [only].

1981 Ancyrodella lobata Branson \& Mehl. - Bultynck \& Hollard, p. 38, pl. 10, figs 9-11.

1981a Ancyrodella lobata Branson \& Mehl. - Perri \& Spalletta, p. 293, pl. 1, fig. 6 [only].

1981 Ancyrodella lobata Branson \& Mehl. - Bultynck \& Jacobs, p. 24, pl. 9, fig. 13 [only].

1982 Ancyrodella lobata Branson \& Mehl. - Mouravieff, p. 114, pl. 3, fig. 6 .

1985 Ancyrodella lobata Branson \& Mehl. - Olivieri, pp. 280, 282, pl. 3, fig. 5.

1985 Ancyrodella lobata Branson \& Mehl. - Klapper \& Lane, pp. 923, 925, figs 14.12, 14.13, 14.16, 14.17.

1986 Ancyrodella lobata Branson \& Mehl. - García-López, p. 454, pl. 3, figs 11-16.

1987 Ancyrodella lobata Branson \& Mehl. - García-López, pp. 62, 63, pl. 3, figs 7-10

1989 Ancyrodella lobata Branson \& Mehl. - Klapper, 1989, p. 457.

1989 Ancyrodella lobata Branson \& Mehl. - Vandelaer et al., p. 330, pl. 2, figs 1, 2.

1989 Ancyrodella aff. lobata Branson \& Mehl. - Vandelaer et al., p. 330, pl. 2, figs 3, 4 .

1992 Ancyrodella lobata Branson \& Mehl. - Helsen \& Bultynck, p. 152, pl. 1, fig. 4. 
1992 Ancyrodella sp. A. - Helsen \& Bultynck, p. 152, pl. 1 , fig. 6 .

1992 Ancyrodella nodosa Ulrich \& Bassler. - Uyeno, p. 72, pl. 16, fig. 6 [only].

1993 Ancyrodella lobata Branson \& Mehl Morphotype 1.Ji \& Ziegler, p. 53, pl. 2, figs 8-10.

1993 Ancyrodella lobata Branson \& Mehl Morphotype 2.Ji \& Ziegler, p. 53, pl. 2, figs 6, 7.

1999 Ancyrodella lobata Branson \& Mehl. - Lazreq, p. 58, pl. 4, figs 5, 6 .

1999 Ancyrodella rotundiloba (Bryant). - Lazreq, p. 60, pl. 4, figs 9, 10 [only].

2000 Ancyrodella lobata Branson \& Mehl. - Çapkinoğlu \& Gedik, p. 84, pl. 3, fig. 15.

2002 Ancyrodella rugosa Branson \& Mehl. - Dzik, p. 590, fig. 25c

2002 Ancyrodella nodosa Ulrich \& Bassler. - Dzik, p. 590, fig. 25e [only].

2002 Ancyrodella lobata Branson \& Mehl. - Dzik, p. 590, fig. 27a-c [only].

? 2006 Ancyrodella nodosa Ulrich \& Bassler. - Savage et al., p. 178, figs 6q, w-y [only].

? 2006 Ancyrodella gigas Youngquist. - Savage et al., p. 180, fig. $5 \mathrm{y}, \mathrm{z}$.

2006 Ancyrodella curvata (Branson \& Mehl) early form. Pisarzowska et al., p. 625, fig. 13f.

2007 Ancyrodella lobata Branson \& Mehl. - Gouwy et al., p. 389, fig. 15 o.

2007 Ancyrodella curvata early form. - Over, p. 1202, figs 11.5, 11.6.

2012 Ancyrodella lobata Branson \& Mehl. - Liao \& Valenzuela-Ríos, p. 824, figs 5a, b [only; fig. 5c-h too fragmentary for confident identification].

2012 Ancyrodella lobata Branson \& Mehl. - Mossoni et al., p. 19, fig. 5.2 .

2012 Ancyrodella curvata Branson \& Meh1 [sic]. - Mossoni et al., p. 19, fig. 5.3 .

2012 Ancyrodella nodosa Ulrich \& Bassler. - Mossoni et al., pp. 19, 21, fig. 5.1 .

2013 Ancyrodella lobata Branson \& Mehl. - Bahrami et al., p. 380 , fig. $7 \mathrm{~m}$, o.

2018 Ancyrodella curvata Branson \& Mehl [sic]. - Huang et al., p. 65, fig. 4.10 .

2018 Ancyrodella rugosa Branson \& Mehl. - Dzik et al., p. 331, fig. 3p (photo reversed) [reillustration of Dzik 2002, fig. 25c].

2018 Ancyrodella nodosa Ulrich \& Bassler.-Dzik et al., p. 331, fig. 3n [only; reillustration of Dzik 2002, fig. 25e].
2018 Ancyrodella lobata Branson \& Mehl. - Dzik et al., p. 331, fig. 3h-j [only; reillustrations of Dzik 2002, fig. $27 \mathrm{a}-\mathrm{c}]$.

2020 Ancyrodella [as Ad.] lobata. - Aboussalam et al., p. 149 , fig. 20.21 .

Diagnosis. - Ancyrodella lobata has a similar platform outline to that of $A$. curvata early form but lacks the strong accessory carina on the outer side posterior of midlength.

Remarks. - Ancyrodella lobata differs from the early form of $A$. curvata, which have closely similar platform outlines, by the absence of a well developed accessory carina on the outer side just posterior of midlength. That position in A. lobata has at most a row of several separated nodes or no such nodes. This is the essential contrast with the $A$. curvata early form. The characteristic almost trapezoidal outline distinguishes both taxa from other species of the genus, including especially $A$. nodosa.

The range of intraspecific variation in Ancyrodella lobata is well exemplified by specimens illustrated in Dzik et al. 2018 (fig. 3h-j, n, p) all identified herein as A. lobata, whereas those authors identified fig. $3 \mathrm{n}$ as A. nodosa, fig. $3 \mathrm{p}$ as $A$. rugosa, and the other three as $A$. lobata. The row of several separated nodes bisecting the outer side just posterior of midlength is absent (fig. 3h) to weak but distinct in the other four specimens that are united by the almost trapezoidal platform outline and the straight secondary carinae set at a narrow angle in all but the specimen in fig. $3 \mathrm{p}$, in which the carinae are only slightly curved. But the curvature of the secondary carinae of $A$. nodosa is much stronger (e.g., Dzik et al. 2018, fig. $31, \mathrm{~m})$ and they form a much wider angle.

The specimens of Savage et al. (2006, figs 5y, z; 6q, $\mathrm{w}-\mathrm{y})$ have a platform outline somewhat resembling that of $A$. lobata but apparently lack the characteristic outer posterior accessory keel.

\section{Summary}

In his monograph on conodonts and ammonoids of the Frasnian of the Holy Cross Mountains, Poland, Dzik (2002, p. 618) stated that "Ancyrodella species are generally very variable and the status of the majority of them is questionable". The analysis and synonymies prepared for the present revision of all the Ancyrodella species, demonstrates how inconsistently these species

Figure 3. All photographs are upper views, magnifications $\times 40$. $\bullet$ A - Ancyrodella gigas Youngquist form 2 Klapper 1989, F54980, WMcP 365-15, FZ 6. • B - Ancyrodella gigas Youngquist cf. form 2 Klapper 1989, F51424 [previously illustrated in Klapper 2009, fig. 1.3.11], HS 364-4a, FZ 7. • C, D - Ancyrodella hamata Ulrich \& Bassler 1926, F54981-54982, HS 364-9, 25, FZ 10, 11. • E, F, G-I - Ancyrodella lobata Branson \& Mehl 1934; E, F- F54983-54984, HS 364-16, FZ 11; G-I - F54985-54987, HS 364-5, FZ 8. 

have been identified and in fact conflated. Thus, any zonation based on Ancyrodella species will remain questionable until the taxonomy is stabilized. A step in that direction is the purpose of the taxonomic revisions proposed herein. All seventeen species of Ancyrodella considered as valid are the subject of this paper, as well as several morphotypes that are intraspecific variants and not separate species.

\section{Acknowledgments}

The late Philip E. Playford, former director of the Geological Survey of Western Australia, was the principal investigator of the Canning Basin Devonian reef complexes from the 1950s' field seasons for almost every year thereafter until the publication of the monograph by Playford, Hocking \& Cockbain (2009). Phil provided the Survey's logistical support, including field vehicles, and assistance in my collecting especially in 1992 and 1995, but also gave critical advice on localities and stratigraphy in the other years (1988, 1990, and 1993). Furthermore, he provided a number of additional collections for conodont processing, including that of GSWA 135107. Robert S. Nicoll then of the Australian Geological Survey Organisation, Canberra, together with Richard W. Brown set up the initial field work in 1988, and greatly assisted in the measuring and collecting of the sections, especially the most important one at Horse Spring (Klapper 2007a). The late Michael R. House of Hull and Southampton Universities gave inestimable advice in the field in 1990, 1993, and 1995, as well as collecting several critical conodont samples in 1989 in addition to his main ammonoid collecting. Ralph Thomas Becker of Münster University also participated in the conodont and ammonoid sample collecting in those four field seasons. Raimund Feist of Montpellier University collected trilobites in the highest Frasnian beds at Horse Spring in the 1995 field season. My longtime colleague, the late William (Bill) T. Kirchgasser of the SUNY College at Potsdam and I collected many sections together in 1990 and had originally planned on writing a joint paper on Canning Basin Frasnian conodonts, including the genera Ancyrodella, Ancyrognathus, and Mesotaxis. The writing of that paper unfortunately did not begin, however, primarily because we instead worked off and on from 1989 until 2014 in the research and writing of the New York Frasnian paper that was not published until 2016 (Klapper \& Kirchgasser 2016).

I am grateful to Roger Hocking and Sarah Martin of the GSWA for providing detailed locality information on Phil Playford's 135107 conodont collection mentioned earlier.

I wish to thank my other longtime colleague, Charles A. Sandberg, emeritus of the U.S. Geological Survey, Denver, for constant encouragement and advice on the writing of this paper during our weekly phone calls from March 2020 when the shutdown from the pandemic began until the present. He does not necessarily agree, however, with the proposed taxonomy and conclusions of this paper nor has he reviewed the manuscript. Thus, errors of interpretation are solely mine. Thanks are extended also to Jerzy Dzik, of the Paleobiological Institute of the Polish Academy of Sciences, Warsaw, who despite our disagreements on taxonomy, has engaged with me in thoughtful and helpful correspondence outlining his views. Many thanks indeed to Claudia Spalletta of the Università di Bologna and Stanislava Vodrážková of the Czech Geological Survey for their constructive reviews. At my request facilitated by Thomas Becker, Sarah Aboussalam, also of Münster University, kindly photographed lower views of the specimens in their figures 20.12, 20.20, and 20.22 (Aboussalam et al. 2020). I wish to dedicate this paper to my very close friend and colleague, Bill Kirchgasser, who passed away suddenly in 2019.

\section{References}

Aboussalam, Z.S. \& Becker, R.T. 2007. New upper Givetian to basal Frasnian conodont faunas from the Tafilalt (Anti-Atlas, southern Morocco). Geological Quarterly 51(4), 345-374.

Aboussalam, Z.S., Becker, R.T., Richter, J., Hartenfels, S., El Hassani, A. \& Eichholt, S. 2020. The unique Devonian of Immouzer-du-Kandar (Middle Atlas basement) biostratigraphy, faunas, and facies development, 127-173. In Becker, R.T, El Hassani, A. \& Aboussalam, Z.S. (eds) Devonian to Lower Carboniferous stratigraphy and facies of the Western Moroccan Meseta: Implications for palaeogeography and structural interpretation. Frontiers in Science and Engineering International Journal 10(1).

Anderson, W.I. 1966. Upper Devonian conodonts and the Devonian-Mississippian boundary of north-central Iowa. Journal of Paleontology 40(2), 395-415.

Bahrami, A., Corradini, C., Over, D.J. \& Yazdi, M. 2013. Conodont biostratigraphy of the upper Frasnian-lower Famennian transitional deposits in the Shotori Range, Tabas area, central-east Iran Microplate. Bulletin of Geosciences 88(2), 369-388. DOI 10.3140/bull.geosci.1353

Bahrami, A., Zamani, F., Corradini, C., Yazdi, M. \& Ameri, H. 2014. Late Devonian (Frasnian) conodonts from the Bahram Formation in the Sar-e-Ashk section, Kerman Province, central-east Iran Microplate. Bollettino della Società Paleontologica Italiana 53(3), 179-188.

BALIŃSKI, A. 1979. Brachiopods and conodonts from the Frasnian of the Debnik anticline, southern Poland. Palaeontologia Polonica 39, 3-95.

Becker, R.T \& House, M.R. 1997. Sea-level changes in the Upper Devonian of the Canning Basin, Western Australia. Courier Forschungsinstitut Senckenberg 199, 129-146.

Becker, R.T. \& Aboussalam, Z.S. 2015. Annexe II. Coupe du secteur de Hassi Nebech, 109-119. In Alvarao, J.-J. et al. (eds) Carte géologique du Maroc au 1/50 000, feuille Tawz, Mémoire explicative, Notes et Mémoires du Service Géologique 551, Rabat.

Becker, R.T., Gradstein, F.M. \& Hammer, O. 2012. The Devonian Period, 559-601. In Gradstein, F.M., OGG, J.G., Schmitz, M. \& OGG, G. (eds) The Geological Time Scale 2012. Elsevier Publisher 2. DOI 10.1016/B978-0-444-59425-9.00022-6 
Becker, R.T., Aboussalam, Z.S., El Hassani, A., Eichholt, S. \& Helling, S. 2020a. The Devonian of the Oued Cherrat Zone (Western Meseta) - review and new data, 27-85. In BECKER, R.T., El Hassani, A. \& Aboussalam, Z.S. (eds) Devonian to Lower Carboniferous stratigraphy and facies of the Western Moroccan Meseta: Implications for palaeogeography and structural interpretation. Frontiers in Science and Engineering International Journal 10(1).

Becker, R.T., Aboussalam, Z.S., El Hassani, A., Hartenfels, S. \& HÜNEKE, H. 2020b. Devonian and basal Carboniferous of the allochthonous nappes at Mrirt (eastern part of Western Meseta) - review and new data, 87-126. In BECKER, R.T., El Hassani, A. \& Aboussalam, Z.S. (eds) Devonian to Lower Carboniferous stratigraphy and facies of the Western Moroccan Meseta: Implications for palaeogeography and structural interpretation. Frontiers in Science and Engineering International Journal 10(1).

Bischoff, G. \& Ziegler, W. 1957. Die Conodontenchronologie des Mitteldevons und des tiefsten Oberdevons. Abhandlungen des Hessischen Landesamtes für Bodenforschung 22, 1-136.

BoogaArd, M. VAN DEN 1983. Conodont faunas from Portugal and southwestern Spain: Part 7. A Frasnian conodont fauna near the Estacao de Cabrela (Portugal). Scripta Geologica 69, 1-17.

Branson, E.B. \& Mehl, M.G. 1933. A study of Hinde's types of conodonts preserved in the British Museum. University of Missouri Studies 8(2), 133-156, 165-167.

Branson, E.B. \& Mehl, M.G. 1934. Conodonts from the Grassy Creek Shale of Missouri. University of Missouri Studies 8(3), 171-259 [imprint 1933].

BRYANT, W.L. 1921. The Genesee conodonts, with descriptions of new species. Buffalo Society of Natural Sciences Bulletin 13(2), 1-59.

Bultynck, P., with contributions by JACOBS, L. 1982. Conodont succession and general faunal distribution across the Givetian-Frasnian boundary beds in the type area, 34-59. In BIGEY, F. et al. Papers on the Frasnian-Givetian boundary. Brussels, Geological Survey of Belgium and Subcommission on Devonian Stratigraphy.

Bultynck, P. 1983. Origin and development of the conodont genus Ancyrodella in the late Givetian - early Frasnian. Fossils and Strata 15, 163-168.

Bultynck, P. 1986. Accuracy and reliability of conodont zones: the Polygnathus asymmetricus "zone" and the GivetianFrasnian boundary. Bulletin de l'Institut royal des Sciences naturelles de Belgique, Sciences de la Terre 56, 269-280.

Bultynck, P. \& Hollard, H. 1981. Distribution comparée de Conodontes et Goniatites dévoniens des plaines du Dra, du Ma'der et du Tafilalt (Maroc). Aardkundige Mededelingen 1, 7-73 [imprint 1980].

Bultynck, P. \& Jacobs, L. 1981. Conodontes et sédimentologie des couches de passage du Givetien au Frasnien dans le Nord du Tafilalt et dans le Ma'der (Maroc présaharien). Bulletin de l'Institut royal des Sciences naturelles de Belgique, Sciences de la Terre 53(2), 1-24.

Bultynck, P., Helsen, S. \& Hayduckiewich, J. 1998. Conodont succession and biofacies in upper Frasnian formations
(Devonian) from the southern and central parts of the Dinant Synclinorium (Belgium) - (Timing of facies shifting and correlation with late Frasnian events). Bulletin de l'Institut royal des Sciences naturelles de Belgique, Sciences de la Terre 68, 25-75.

ÇAPKINOĞLU, S. \& GediK, I. 2000. Late Devonian conodont fauna of the Gümüsali Formation, the eastern Taurides, Turkey. Turkish Journal of Earth Sciences 9, 69-89.

Clark, D.L. \& Ethington, R.L. 1967. Conodonts and zonation of the Upper Devonian in the Great Basin. Geological Society of America Memoir 103, 1-94.

DOI 10.1130/MEM103-p1

Druce, E.C. 1976. Conodont biostratigraphy of the Upper Devonian reef complexes of the Canning Basin, Western Australia. Australia Bureau of Mineral Resources, Geology and Geophysics Bulletin 158, 1-303.

DzIK, J. 1985. Typologic versus population concepts of chronospecies: Implications for ammonite biostratigraphy. Acta Palaeontologica Polonica 30(1-2), 71-92.

DzIK, J. 1990. The concept of chronospecies in ammonites, 273-289. In Pallini, G. et al. (eds) Atti del secondo convegno internazionale Fossili Evoluzione Ambiente, Pergola 25-30 ottobre 1987. Comitato Centenario Raffaele Piccinini, Pergola PS. .

DzIK, J. 2002. Emergence and collapse of the Frasnian conodont and ammonoid communities in the Holy Cross Mountains, Poland. Acta Palaeontologica Polonica 47(4), 565-650.

Dzik, J., Swis, P. \& Phong, N.D. 2018. The Frasnian-Famennian boundary in Vietnam and evolutionary meaning of FADs and LADS. Newsletters on Stratigraphy 51(3), 327-342. DOI 10.1127/nos/2017/0418

Ethington, R.L. \& FuRnish, W.M. 1962. Silurian and Devonian conodonts from Spanish Sahara. Journal of Paleontology 36(6), 1253-1290.

Fuchs, A. 1987. Conodont biostratigraphy of the Elbingerode reef complex, Harz Mountains. Acta Geologica Polonica 37(1-2), 33-50.

García-LóPez, S. 1981. Nueva especie de Ancyrodella (Conodonta) del Devónico Superior de la Cordillera Cantabrica (no. de España). Estudios Geológicos 37, 263-267.

GARCíA-López, S. 1986. Basis for the establishment of a new phylogeny of the genus Ancyrodella. Revista Española de Micropaleontología 18, 443-456.

GARCía-López, S. 1987. Los conodontos y su aplicación al estudio de las divisions cronostratigraficas mayores del Devónico Asturleonés (España). Publicaciones Especiales del Boletín Geológico y Minero, Instituto Geológico y Minero de España, 1-112.

García-López, S. \& SANZ- López, J., with contributions by G.N. SARMiento. 2002a. The Palaeozoic succession and conodont biostratigraphy of the section between Cape Peñas and Cape Torres (Cantabrian Coast, NW Spain), 125-161. In GARCíALópez, S. \& Bastida, F. (eds) Palaeozoic conodonts from northern Spain. ECOS VIII. Publicaciones del Instituto Geológico y Minero de España. Serie: Cuadernos del Museo Geominero 1.

García-López, S. \& SAnz-López, J. 2002b. Devonian to Lower 
Carboniferous conodont biostratigraphy of the Bernesga Valley section (Cantabrian Zone, NW Spain), 163-205. In García-López, S. \& Bastida, F. (eds) Palaeozoic conodonts from northern Spain. ECOS VIII. Publicaciones del Instituto Geológico y Minero de España. Serie: Cuadernos del Museo Geominero 1 .

Gatovsky, Yu., Stupakova, A.V., Kalmykov, G.A., Korobova, N.I., Suslova, A.A., Sautkin, R.S. \& Kalmykov, D.G. 2016. New data on the biostratigraphy and facies types of Upper Carboniferous [sic] Domanik sections in the Volga-Ural Basin. Moscow University Geology Bulletin 71(1), 58-70. DOI 10.3103/S014587521505004X

Gholamalian, H., Hairapetian, V., Barfehei, N., Mangelian, S. \& FARIDI, P. 2013. Givetian-Frasnian boundary conodonts from Kerman Province, central Iran. Rivista Italiana di Paleontologia e Stratigrafia 119(2), 133-146.

Glenister, B.F. \& Klapper, G. 1966. Upper Devonian conodonts from the Canning Basin, Western Australia. Journal of Paleontology 40(4), 777-842.

Gouwy, S. \& Bultynck, P. 2000. Graphic correlation of Frasnian sections (Upper Devonian) in the Ardennes, Belgium. Bulletin de l'Institut royal des Sciences naturelles de Belgique, Sciences de la Terre 70, 25-52.

Gouwy, S., Haydukiewicz, J. \& Bultynck, P. 2007. Conodontbased graphic correlation of upper Givetian-Frasnian sections of the eastern Anti-Atlas (Morocco). Geological Quarterly 51(4), 375-392.

Gouwy, S., Liao, J.-C. \& Valenzuela-Ríos, J.I. 2013. Eifelian (Middle Devonian) to Lower Frasnian (Upper Devonian) conodont biostratigraphy in the Villech section (Spanish Central Pyrenees). Bulletin of Geosciences 88(2), 315-338. DOI 10.3140/bull.geosci.1341

Helms, J. 1963. Zur "Phylogenese" und Taxionomie von Palmatolepis (Conodontida, Oberdevon). Geologie 12(4), 449-485.

Helsen, S. \& Bultynck, P. 1992. Conodonts and megafauna from two sections at Nismes and Mariembourg (Frasnian of the southern flank of the Dinant Synclinorium, Belgium). Annales de la Géologique de Belgique 115(1), 145-157.

Hinde, G.J. 1879. On conodonts from the Chazy and Cincinnati Group of the Cambro-Silurian, and from the Hamilton and Genesee-Shale divisions of the Devonian, in Canada and the United States. Quarterly Journal of the Geological Society of London 35, 351-369.

DOI 10.1144/GSL.JGS.1879.035.01-04.23

Huang, C., Song, J., Shen, J. \& Gong, Y. 2018. The influence of the Late Devonian Kellwasser events on deep-water ecosytems: Evidence from palaeontological and geochemical records from South China. Palaeogeography, Palaeoclimatology, Palaeoecology 504, 60-74.

DOI 10.1016/j.palaeo.2018.05.006

Huddle, J.W. 1934. Conodonts from the New Albany Shale of Indiana. Bulletins of American Paleontology 21, 1-137.

Huddle, J.W. 1968. Redescription of Upper Devonian conodont genera and species proposed by Ulrich and Bassler in 1926. U. S. Geological Survey Professional Paper 578, I-IV, 1-55. DOI $10.3133 /$ pp578
Huddle, J.W., assisted by RePetski, J.E. 1981. Conodonts from the Genesee Formation in western New York. U. S. Geological Survey Professional Paper 1032-B, I-VI, B1-B66. DOI 10.3133/pp1032B

Irwin, S.E.B. \& Orchard, M.J. 1991. Upper Devonian Lower Carboniferous conodont biostratigraphy of the Earn Group and overlying units, northern Canadian Cordillera. Geological Survey of Canada Bulletin 417, 185-213. DOI 10.4095/132438

Ji, Q. et al. 1986. Research on the Middle/Upper Devonian boundary at Dale, Guangxi. Acta Micropalaeontologica Sinica 3(1), 89-100.

JI, Q. 1989a. On the Frasnian-Famennian mass extinction event in South China. Courier Forschungsinstitut Senckenberg 117, 275-301.

Ji, Q. 1989b. On the Frasnian conodont biostratigraphy in the Guilin area of Guangxi, South China. Courier Forschungsinstitut Senckenberg 117, 303-319.

Ji, Q. \& Ziegler, W. 1993. The Lali section: An excellent reference section for Upper Devonian in South China. Courier Forschungsinstitut Senckenberg 157, 1-183.

Khalymbadzha, V.G. \& Chernysheva, N.G. 1970. Konodonty rod Ancyrodella iz Devonskikh otlozheniy Volgo-Kamskogo kraya i ikh stratigraficheskoe znachenie, 81-103. In Biostratigrafiya I Paleontologiya Paleozoyskikh otlozheniy vostoka Russkoy Platformy I zapadnogo priural'ya. Izdatel'stvo Kazanskogo Universiteta Vypusk 1. [in Russian]

Kirchgasser, W.T. 1970. Conodonts from near the Middle/ Upper Devonian boundary in north Cornwall. Palaeontology 13(3), 335-354.

KIRCHGASSER, W.T. 1994. Early morphotypes of Ancyrodella rotundiloba at the Middle-Upper Devonian boundary, Genesee Formation, west-central New York. New York State Museum Bulletin 481, 117-134.

Kirchgasser, W.T., Baird, G.C. \& Brett, C.E. 2020. Ammonoids from the Tully Formation and Harrell Shale in Pennsylvania: Markers of sea-level highstands in the Middle to Late Devonian transition, Appalachian foreland basin, eastern North America, 197-224. In Avery, K.L., Hasson, K.O. \& Diecchio, R.J. (eds) The Appalachian Geology of John M. Dennison: Rocks, People, and a Few Good Restaurants along the Way. Geological Society of America Special Paper 545. DOI 10.1130/2020.2545(10)

KLApper, G. 1980. Conodont systematics, 99-104, 112-115. In Johnson, J.G., Klapper, G. \& Trojan, W.R. Brachiopod and conodont successions in the Devonian of the northern Antelope Range, central Nevada. Geologica et Palaeontologica 14, 77-116.

Klapper, G. 1985. Sequence in conodont genus Ancyrodella in Lower asymmetricus Zone (earliest Frasnian, Upper Devonian) of the Montagne Noire, France. Palaeontographica Abteilung A 188(1-3), 19-34.

Klapper, G. 1989. The Montagne Noire Frasnian (Upper Devonian) conodont succession, 449-468. In McMillan, N.J., Embry, A.F. \& Glass, D.J. (eds) Devonian of the World. Calgary, Canadian Society of Petroleum Geologists Memoir 14(III), [imprint 1988]. 
KLApper, G. 1990. Frasnian species of the Late Devonian conodont genus Ancyrognathus. Journal of Paleontology 64(6), 998-1025. DOI 10.1017/S0022336000020072

KLApper, G. 2000. Species of Spathognathodontidae and Polygnathidae (Conodonta) in the recognition of Upper Devonian stage boundaries. Courier Forschungsinstitut Senckenberg 220, 153-159.

KLAPPER, G. 2007a. Frasnian (Upper Devonian) conodont succession at Horse Spring and correlative sections, Canning Basin, Western Australia. Journal of Paleontology 81(3), 513-537. DOI 10.1666/05088.1

KLAPPER, G. 2007b. Conodont taxonomy and the recognition of the Frasnian/Famennian (Upper Devonian) stage boundary. Stratigraphy 4(1), 67-76.

Klapper, G. 2009. Upper Devonian conodonts in the Canning Basin. Appendix 1, 405-413. In Playford, P.E., Hocking, R.M. \& Cockbain, A.E. Devonian Reef Complexes of the Canning Basin, Western Australia. Geological Survey of Western Australia Bulletin 145, 1-444.

KLAPPER, G. 2017. The occurrence of Polygnathus tuberculatus in lag deposits near the Middle-Upper Devonian boundary and its stratigraphic range in the conodont zonation. Stratigraphy 14(1-4), 217-222. DOI 10.29041/strat.14.1-4.217-222

Klapper, G. \& Foster, C.T., JR 1993. Shape analysis of Frasnian species of the Late Devonian conodont genus Palmatolepis. The Paleontological Society Memoir 32, 1-35.

DOI 10.1017/S0022336000062168

Klapper, G. \& Kirchgasser, W.T. 2016. Frasnian Late Devonian conodont biostratigraphy in New York: graphic correlation and taxonomy. Journal of Paleontology 90(3), 525-554. DOI 10.1017/jpa.2015.70

Klapper, G. \& Lane, H.R. 1985. Upper Devonian (Frasnian) conodonts of the Polygnathus biofacies, N.W.T., Canada. Journal of Paleontology 59(4), 904-951.

Klapper, G. \& Philip, G.M. 1972. Familial classification of reconstructed Devonian conodont apparatuses. Geologica et Palaeontologica SB1, 97-113.

Klapper, G. \& VodrÁžKovÁ, S. 2013. Ontogenetic and intraspecific variation in the late Emsian - Eifelian (Devonian) conodonts Polygnathus serotinus and P. bultyncki in the Prague Basin (Czech Republic) and Nevada (western U.S.). Acta Geologica Polonica 63(2), 153-174. DOI 10.2478/agp-2013-0006

Klapper, G., Feist, R., Becker, R.T. \& House, M.R. 1993. Definition of the Frasnian/Famennian Stage boundary. Episodes 16(4), 433-441.

DOI 10.18814/epiiugs/1993/v16i4/003

Klapper, G., Uyeno, T.T., Armstrong, D.K. \& Telford, P.G. 2004. Conodonts of the Williams Island and Long Rapids formations (Upper Devonian, Frasnian-Famennian) of the Onakawana B Drillhole, Moose River Basin, northern Ontario, with a revision of Lower Famennian species. Journal of Paleontology 78(2), 371-387.

DOI 10.1666/0022-3360(2004)078<0371:COTWIA $>2.0 . C O ; 2$

Königshof, P., Carmichael, S.K., Waters, J., Jansen, U., BahraMI, A., Boncheva, I. \& YAzDI, M. 2017. Palaeoenvironmental study of the Palaeotethys Ocean: the Givetian-Frasnian boundary of a shallow-marine environment using combined facies analysis and geochemistry (Zefreh section/central Iran). Palaeobiodiversity and Palaeoenvironments 97, 517-540. DOI 10.1007/s12549-016-0253-0

Kralick, J.A. 1994. The conodont genus Ancyrodella in the middle Genesee Formation (Lower Upper Devonian, Frasnian), western New York. Journal of Paleontology 68(6), 1384-1395. DOI 10.1017/S0022336000034351

Krebs, W. 1959. Zur Grenze Mittel-/Ober-Devon und zur Gliederung des obersten Mittel-Devons und der tieferen Adorf-Stufe nach Conodonten. Senckenbergiana lethaea 40(5-6), 367-387.

Krebs, W. \& Ziegler, W. 1966. Über die Mitteldevon/Oberdevon-Grenze in der Riffazies bei Aachen. Fortschritte in der Geologie von Rheinland und Westfalen 9, 731-754 [imprint 1965].

LAzReQ, N. 1999. Biostratigraphie des conodontes du Givétien au Famennien du Maroc central - Biofaciès et événement Kellwasser. Courier Forschungsinstitut Senckenberg 214, $1-111$.

Li, H., MA, X. \& Wei, L. 2009. A Middle-Upper Devonian boundary section in the open platform, platform margin facies of Guilin, South China. Acta Geologica Sinica 83(3), 524-534. DOI 10.1111/j.1755-6724.2009.00048.x

Liao, J.-C. \& Valenzuela-Ríos, J.I. 2008. Givetian and early Frasnian conodonts from the Compte section (Middle-Upper Devonian, Spanish Central Pyrenees). Geological Quarterly 52(1), 1-18.

Liao, J.-C. \& Valenzuela-Ríos, J.I. 2012. Upper Givetian and Frasnian (Middle and Upper Devonian) conodonts from Ampriú (Aragonian Pyrenees, Spain): Global correlations and palaeogeographic relations. Palaeontology 55(4), 819-842. DOI 10.1111/j.1475-4983.2012.01150.x

Liao, J.-C. \& Valenzuela-Ríos, J.I. 2013. The Middle and Upper Devonian conodont sequence from La Guardia D'Àres sections (Spanish Central Pyrenees). Bulletin of Geosciences 88(2), 339-368. DOI 10.3140/bull.geosci.1348

Liao, J.-C., Girard, C., Valenzuela-Ríos, J.I. \& Feist, R. 2019. New conodont data from the Middle-Upper Devonian boundary stratotype section at $\mathrm{Col}$ du Puech de la Suque (Montagne Noire, France), p. 188. In Petti, F.M. et al. (eds) $3^{\text {rd }}$ International Congress on Stratigraphy, strati 2019, 2-5 July 2019, Milano, Italy, Abstract Book.

Mahboubi, A., Feist, R., Cornée, J.-J., Mehadji, A.O. \& Girard, C. 2015. Frasnian (Late Devonian) conodonts and environment at the northern margin of the Algerian Sahara platform: the Ben Zireg section. Geological Magazine 152(5), 844-857. DOI /10.1017/S0016756814000715

Matthews, S.C. \& Riddolls, B.W. 1984. Appendix 1. Devonian conodont faunas, 34-37, 173-175. In Selwood, E.B. et al. Geology of the country around Newton Abbot. British Geological Survey Memoir for 1:50 000 geological sheet 339, New Series.

Miller, A.K. \& Youngquist, W. 1947. Conodonts from the type section of the Sweetland Creek Shale in Iowa. Journal of Paleontology 21(6), 501-517.

Miller, C.G. 2007. Growth in early species of the conodont 
Ancyrodella and implications for correlation of the MiddleUpper Devonian boundary. Geological Quarterly 51(4), 443-452.

Mossoni, A., Corradini, C. \& Pondrelli, M. 2012. Famennian (Late Devonian) conodonts from the Pizzul west section (Carnic Alps, Italy). Gortania Geologia, Paleontologia, Paletnologia 34, 13-36.

Mound, M.C. 1968. Upper Devonian conodonts from southern Alberta. Journal of Paleontology 42(2), 444-524.

MouraviefF, A.N. 1982. Conodont stratigraphic scheme of the Frasnian of the Ardennes, 101-118. In BigeY, F. et al. Papers on the Frasnian-Givetian boundary. Geological Survey of Belgium and Subcommission on Devonian Stratigraphy. Brussels.

Müller, K.J. 1956. Taxonomy, nomenclature, orientation, and stratigraphic evaluation of conodonts. Journal of Paleontology 30(6), 1324-1340.

Müller, K.J. \& Clark, D.L. 1967. Early Late Devonian conodonts from the Squaw Bay Limestone in Michigan. Journal of Paleontology 41(4), 902-919.

Müller, K.J. \& Müller, E.M. 1957. Early Upper Devonian (Independence) conodonts from Iowa, part I. Journal of Paleontology 31(6), 1069-1108.

Navas-Parejo, P., Rodríguez-Cañero, R., Somma, R., MartínAlgarra, A. \& Perrone, V. 2009. The Frasnian Upper Kellwasser event and a lower Famennian stratigraphic gap in Calabria (southern Italy). Palaeobiodiversity and Palaeoenvironments 89, 111-118. DOI 10.1007/s12549-009-0006-4

NaZarova, V.M., Kononova, L.I., Kulashova, T.A. \& Zaytseva, E.L. 2019. Biostratigraphic characteristic of the Frasnian age (Upper Devonian) reference section in the central Voronezh Anteclise middle part (Well 16, Shchigry-16 borehole, Nizhnekrasnoe Village, Kursky region). Stratigraphy and Geological Correlation 27(2), 80-106. DOI 10.31857/S0869-592X27280-106

NicolL, R.S. 1984. Conodont distribution in the marginal-slope facies of the Upper Devonian reef complex, Canning Basin, Western Australia. Geological Society of America Special Paper 196, 127-141. DOI 10.1130/SPE196-p127

Olivieri, R. 1985. Middle and Late Devonian conodonts from southwestern Sardinia. Bollettino della Società Paleontologica Italiana 23(2), 269-310 [imprint 1984].

Orchard, M.J. 1978. The conodont biostratigraphy of the Devonian Plymouth Limestone, south Devon. Palaeontology 21(4), 907-955.

Orchard, M.J. 1989. Conodonts from the Frasnian-Famennian boundary interval in western Canada, 35-52. In McMillan, N.J., Embry, A.F. \& Glass, D.J. (eds) Devonian of the World. Calgary, Canadian Society of Petroleum Geologists Memoir 14(III) [imprint 1988].

Over, D.J. 1997. Conodont biostratigraphy of the Java Formation (Upper Devonian) and the Frasnian-Famennian boundary in western New York State. Geological Society of America Special Paper 321, 161-177.

DOI 10.1130/0-8137-2321-3.161

Over, D.J. 2007. Conodont biostratigraphy of the Chattanooga
Shale, Middle and Upper Devonian, southern Appalachian Basin, eastern United States. Journal of Paleontology 81(6), 1194-1217. DOI 10.1666/06-056R.1

Over, D.J. \& Rhodes, M.K. 2000. Conodonts from the upper Olentangy Shale (Upper Devonian, central Ohio) and stratigraphy across the Frasnian-Famennian boundary. Journal of Paleontology 74(1), 101-112.

DOI 10.1666/0022-3360(2000)074<0101:CFTUOS $>2.0 . C O ; 2$

Over, D.J., Hopkins, T.H., Brill, A. \& Spaziani, A.L. 2003. Age of the Middlesex Shale (Upper Devonian, Frasnian) in New York State. Courier Forschungsinstitut Senckenberg 242, 217-223.

Over, D.J., Baird, G.C. \& Kirchgasser, W.T. 2013. Middle Upper Devonian strata along the Lake Erie Shore, western New York. New York State Geological Association $85^{\text {th }}$ Annual Meeting, Department of Geosciences, SUNY Fredonia, Fredonia, New York, 1-36.

Ovnatanova, N.S. \& Kononova, L.I. 2001. Conodonts and Upper Devonian (Frasnian) biostratigraphy of central regions of Russian Platform. Courier Forschungsinstitut Senckenberg 233, 1-115.

Ovnatanova, N.S. \& Kononova, L.I. 2008. Frasnian conodonts from the Eastern Russian Platform. Paleontological Journal 42(10), 997-1166.

DOI 10.1134/S0031030108100018

Ovnatanova, N.S., Kononova, L.I., Kolesnik, L.S. \& Gatovsky, YU. 2017. Upper Devonian conodonts of northeastern European Russia. Paleontological Journal 51(10), 973-1165. DOI 10.1134/S003103011710001X

ÖZKAN, R. et al. 2019. Givetian/Frasnian (Middle/Upper Devonian) transition in the eastern Taurides, Turkey. Turkish Journal of Earth Sciences 28, 207-231.

DOI 10.3906/yer-1804-20

Perri, M.C. \& Spalletta, C. 1981a. Conodonti e biozonatura del Frasniano (Devoniano sup.) di Pramosio, Alpi Carniche. Bollettino della Società Paleontologica Italiana 19(2), 281-310 [imprint 1980].

Perri, M.C. \& Spalletta, C. 1981 b. Ancyrodella pramosica $n$. sp. from the Lower Frasnian of the Carnic Alps.Bollettino della Società Paleontologica Italiana 20(1), 93-98.

Pisarzowska, A., Sobstel, M. \& Racki, G. 2006. Conodontbased event stratigraphy of the Early-Middle Frasnian transition of the South Polish carbonate shelf. Acta Palaeontologica Polonica 51(4), 609-646.

Pisarzowska, A., Becker, R.T., Aboussalam, Z.S., Szczerba, M., Sobień, K., Kremer, B., Owocki, K. \& Racki, G. 2020. Middlesex/punctata Event in the Rhenish Basin (Padberg section, Sauerland, Germany) - Geochemical clues to the early-middle Frasnian perturbation of global carbon cycle. Global and Planetary Change 191, 1-14.

DOI 10.1016/j.gloplacha.2020.103211

Playford, P.E., Hocking, R.M. \& Cockbain, A.E. 2009. Devonian Reef Complexes of the Canning Basin, Western Australia. Geological Survey of Western Australia Bulletin 145, 1-444.

Pollock, C.A. 1968. Lower Upper Devonian conodonts from Alberta, Canada. Journal of Paleontology 42(2), 415-443. 
Pölsler, P. 1969. Conodonten aus dem Devon der Karnischen Alpen (Findenigkofel, Österreich). Jahrbuch der Geologischen Bundesanstalt 112, 399-440.

Racki, G. \& Bultynck, P. 1993. Conodont biostratigraphy of the Middle to Upper Devonian boundary beds in the Kielce area of the Holy Cross Mts. Acta Geologica Polonica 43(1-2), $1-25$.

Racki, G. \& Wrzolek, T. 1989. Middle-Upper Devonian boundary: ambiguous reality of its stratotype. Courier Forschungsinstitut Senckenberg 110, 231-236.

Rodríguez-Cañero, R. \& Martín-Algarra, A. 2014. Frasnian-Famennian crisis in the Malaguide complex (Betic Cordillera, Spain). Terra Nova 26, 38-54.

DOI 10.1111/ter.12068

SAndberg, C.A., Ziegler, W. \& Bultynck, P. 1989. New standard conodont zones and early Ancyrodella phylogeny across Middle-Upper Devonian boundary. Courier Forschungsinstitut Senckenberg 110, 195-229.

SAndberg, C.A., Ziegler, W., Dreesen, R. \& Butler, J.L. 1992. Conodont biochronology, biofacies, taxonomy, and event stratigraphy around Middle Frasnian Lion Mudmound (F2h), Frasnes, Belgium. Courier Forschungsinstitut Senckenberg $150,1-87$.

Sandberg, C.A., Hasenmueller, N.R. \& Rexroad, C.B. 1994. Conodont biochronology, biostratigraphy, and biofacies of Upper Devonian part of New Albany Shale, Indiana. Courier Forschungsinstitut Senckenberg 168, 227-253.

Savage, N.M. 1992. Late Devonian (Frasnian and Famennian) conodonts from the Wadleigh Limestone, southeastern Alaska. Journal of Paleontology 66(2), 277-292. DOI $10.1017 / \mathrm{S} 0022336000033795$

SAvage, N.M. 2013. Late Devonian conodonts from northwestern Thailand. 48 pp. Bourland Printing/Trinity Press, Eugene, Oregon.

SAVAGE, N.M. 2019. Frasnian-Famennian transition in western Thailand: conodonts, biofacies, eustatic changes, extinction. Journal of Paleontology 93(3), 476-495. DOI 10.1017/jpa.2018.96

Savage, N.M. \& Yudina, A.B. 2001. Late Devonian (Frasnian) conodonts from the Timan-Pechora Basin, Russia. Journal of the Czech Geological Society 46(3-4), 287-298.

SAvage, N.M., SARdsud, A. \& Buggisch, W. 2006. Late Devonian conodonts and the global Frasnian-Famennian extinction event, Thong Pha Phum, western Thailand. Palaeoworld 15, 171-184. DOI 10.1016/j.palwor.2006.07.005

SchÜLKe, I. 1995. Evolutive Prozesse bei Palmatolepis in der frühen Famenne-Stufe (Conodonta, Ober-Devon). Göttinger Arbeiten zur Geologie und Paläontologie 67, 1-108.

SCHÜLKe, I. 1997. Conodont clusters and multielement reconstructions from the Upper Kellwasser horizon at La Serre (Late Frasnian, Montagne Noire, southern France). Geologica et Palaeontologica 31, 37-66.

SCHÜLKE, I. 1999. Conodont multielement reconstructions from the early Famennian (Late Devonian) of the Montagne Noire (southern France). Geologica et Palaeontologica SB3, $1-123$.

SEddon, G. 1970a. Frasnian conodonts from the Sadler Ridge-
Bugle Gap area, Canning Basin, Western Australia. Journal of the Geological Society of Australia 16(2), 723-753.

DOI 10.1080/00167617008728711

SEddon, G. 1970b. Pre-Chappel conodonts of the Llano Region, Texas. Bureau of Economic Geology Report of Investigations 68, 1-130. DOI 10.23867/RI0068D

Soboleva, M.A. \& Sobolev, D.B. 2019. The Late Devonian Upper Kellwasser event in the deep-water deposits of the western slope of the subpolar Urals (Kozhym River section). Vestnik Institut of Geology Komi Scientific Center Ural Branch, Russian Academy of Sciences 2019(11), 9-19.

DOI 10.19110/2221-1381-2019-11-9-19

Spalletta, C. \& Perri, M.C. 1998a. Stop 2.1B - Givetian and Frasnian conodonts from the Pramosio 327 section (Carnic Alps, Italy), 190-197. In Perri, M.C. \& Spalletta, C. (eds) Southern Alps Field Trip Guidebook. ECOS VII. Giornale di Geologia Serie 3a, 60, Special Issue.

Spalletta, C. \& Perri, M.C. 1998b. Stop 2.2 - The FrasnianFamennian boundary at the Pramosio A section (Carnic Alps, Italy), 198-205. In Perri, M.C. \& Spalletta, C. (eds) Southern Alps Field Trip Guidebook. ECOS VII. Giornale di Geologia Serie 3a, 60, Special Issue.

STAUFFER, C.R. 1938. Conodonts of the Olentangy Shale. Journal of Paleontology 12(5), 411-443.

Sweet, W.C. 1988. The Conodonta: Morphology, Taxonomy, Paleoecology, and Evolutionary History of a Long-Extinct Animal Phylum. Oxford Monographs on Geology and Geophysics 10, Clarendon Press, Oxford, 1-212.

SzULCZEwSKI, M. 1971. Upper Devonian conodonts, stratigraphy and facial development in the Holy Cross Mts. Acta Geologica Polonica 21(1), 1-129.

Tagarieva, R.C. 2013. Conodont biodiversity of the FrasnianFamennian boundary interval (Upper Devonian) in the southern Urals. Bulletin of Geosciences 88(2), 297-314. DOI 10.3140/bull.geosci.1344

Telnova, O., Soboleva, M. \& Sobolev, D. 2019. Upper Devonian Cristatiskkorites delicquescens palynozone and its correlation (Timan-north Urals region), 253-261. In Alekseev, A. et al. (eds) Proceedings Kazan Golovkinsky stratigraphic meeting 2019. Kazan Federal University Institute of Geology and Petroleum Technologies.

Ulrich, E.O. \& BAssler, R.S. 1926. A classification of the toothlike fossils, conodonts, with descriptions of American Devonian and Mississippian species. U. S. National Museum Proceedings 68(12), 1-63. DOI 10.5479/si.00963801.68-2613.1

Uyeno, T.T. 1967. Conodont zonation, Waterways Formation (Upper Devonian), northeastern and central Alberta. Geological Survey of Canada Paper 67(30), 1-21. DOI 10.4095/100913

Uyeno, T.T. 1974. Conodonts of the Waterways Formation (Upper Devonian) of northeastern and central Alberta. Geological Survey of Canada Bulletin 232, 1-93. DOI 10.4095/103476

Uyeno, T.T. 1991. Pre-Famennian Devonian conodont biostratigraphy of selected intervals in the eastern Canadian Cordillera. Geological Survey of Canada Bulletin 417, 129-161. DOI 10.4095/132436 
Uyeno, T.T. 1992. Conodonts, 71-79, 122-133. In Norris, A.W., Uyeno, T.T., Sartenaer, P. \& Telford, P.G. Brachiopod and conodont faunas from the uppermost Williams Island Formation and lower Long Rapids Formation (Middle and Upper Devonian), Moose River Basin, northern Ontario. Geological Survey of Canada Bulletin 434, 1-133.

Uyeno, T.T. \& Wendte, J.C. 2005. Conodont biostratigraphy and physical stratigraphy in two wells of the Beaverhill Lake Group, Upper Middle to Lower Upper Devonian, central Alberta, Canada. Bulletins of American Paleontology 369, 151-171.

Vandelaer, E., Vandormael, C. \& Bultynck, P. 1989. Biofacies and refinement of conodont succession in the lower Frasnian (Upper Devonian) of the type area (Frasnes-Nimes, Belgium). Courier Forschungsinstitut Senckenberg 117, 321-351.

Weary, D.J. \& Harris, A.G. 1994. Early Frasnian (Late Devonian) conodonts from the Harrell Shale, Western Foreland Fold-and-Thrust Belt, West Virginia, Maryland, and Pennsylvania Appalachians, U.S.A. Courier Forschungsinstitut Senckenberg 168, 195-225.

Yatskov, S.V. \& KuZ'min, A.V. 1992. Comparison of ammonoid and conodont assemblages in Lower Frasnian of south Timan. Bulletin of the Moscow Society of Natural History Research Department of Geology 67(1), 85-90. [in Russian]

YoungQuist, W. 1947. A new Upper Devonian conodont fauna from Iowa. Journal of Paleontology 21(2), 95-112.

Zhang, X., Over, D.J., Ma, K., Gong, Y. 2019. Upper Devonian conodont zonation, sea-level changes and bio-events in offshore carbonate facies Lali section, South China. Palaeogeography, Palaeoclimatology, Palaeoecology 531, 1-23. DOI 10.1016/j.palaeo.2019.05.041

Ziegler, W. 1958. Conodontenfeinstratigraphische Untersuchungen an der Grenze Mitteldevon/Oberdevon und in der Adorfstufe. Notizblatt des Hessischen Landesamtes für Bodenforschung zu Wiesbaden 87, 7-77.

ZIEGLER, W. 1962a. Phylogenetische Entwicklung stratigraphisch wichtiger Conodonten-Gattungen in der Manticoceras-Stufe (Oberdevon, Deutschland). Neues Jahrbuch für Geologie und Paläontologie Abhandlungen 114(2), 142-168.

Ziegler, W. 1962b. Taxionomie und Phylogenie Oberdevonischer Conodonten und ihre stratigraphische Bedeutung. Abhandlungen des Hessischen Landesamtes für Bodenforschung 38, 1-166.

ZIEGLER, W. 1973. Ancyrodella rotundiloba binodosa, 35-36, Ancyrodella rotundiloba rotundiloba, 29-31, Ancyrodella rotundiloba alata, 33-34. In ZiegLer, W. (ed.) Catalogue of Conodonts, Volume I. 504 pp. E. Schweizerbart'sche Verlagsbuchhandlung, Stuttgart.

Ziegler, W. \& Sandberg, C.A. 1990. The Late Devonian Standard Conodont Zonation. Courier Forschungsinstitut Senckenberg 121, 1-115.

Ziegler, W., Ovnatanova, N. \& Kononova, L. 2000. Devonian polygnathids from the Frasnian of the Rheinisches Schiefergebirge, Germany, and the Russian Platform. Senckenbergiana lethaea 80(2), 593-645.

DOI 10.1007/BF03043367

\section{Appendix}

Localities of illustrated specimens, all from the Canning Basin, Western Australia. Frasnian Zone (FZ) given in the figure caption for each specimen.

Capped-Oncolite locality, Sadler Limestone, section on west flank of McWhae Ridge, section of Nicoll (1984, section WCB 811, p. 131, fig. 5 loc.1, fig. 6; Klapper 2009, p. 410), AMG Zone 52, $92088 \mathrm{E}{ }_{79} 26291 \mathrm{~N}$, capped oncolite bed is directly overlain by the straight nautiloid bed, sample 3 is from the top of the nautiloid bed, $20-32 \mathrm{~cm}$ above base of bed. Collected by GK and W.T. Kirchgasser, 1990.

Horse Spring (HS, section 364), Virgin Hills Formation, northern Horse Spring Range, base of section about $200 \mathrm{~m}$ SSE of Horse Spring, base of section is at GPS AMG Zone 52, ${ }_{1} 86077 \mathrm{E}_{79} 85602 \mathrm{~N}$; the F/F boundary in this section is at GPS AMG Zone 52, ${ }_{1} 86034 \mathrm{E}_{79} 85650$ N. Description also in Klapper (2007a, p. 536; 2009, p. 410). Location shown in Becker \& House (1997, fig. 2 and F/F boundary in fig. 6). Bed numbers and stratigraphic position are given in meters above base of section from which specimens illustrated in figs 1-3 were derived (see also Klapper 2007a, tables 1-3). Bed numbers are all preceded by section number 364: $4 \mathrm{a}=0.64-0.79,5=0.93-1.05,9=1.8-2.0,12=2.5-2.6,16=3.75-3.9,18=4.1-4.3,25=5.7-6.0,34=8.15-8.35,43=10.7-10.8$, $45=11.0-11.25,70=31.1-31.25,71=31.9-32.0$. Measured and collected by GK, R.S. Nicoll, and R.W. Brown in 1988 (additional re-collections in 1990 and 1995, Klapper 2007a, p. 536).

Outcamp Hill, Sadler Limestone, SW end of Pillara Range, about 1.3 km NE of the hill, Limestone Billy Hills area, AMG Zone 51, ${ }_{07} 92200 \mathrm{E}_{79} 61950 \mathrm{~N}$, spot sample collected by Philip E. Playford in 1999, PEP field book 19, p. 33 bottom, point 45, sample GSWA 135107.

Timanites Hill (TH, section 370), Gogo Formation, central Bugle Gap area (= WAPET D locality of Glenister \& Klapper (1966, p. 836, fig. 1, tab. 9), location also shown in Becker \& House (1997, fig. 2, 370 indicated in Bugle Gap). AMG Zone 52, $88200 \mathrm{E}$ ${ }_{79} 32400$ N. Fuller description given in Klapper \& Kirchgasser (2016, p. 552). Bed designations and stratigraphic position are given in 
meters above base of exposed section, from which specimens illustrated in fig. 1 were derived. Bed designations are all preceded by section number 370: $1=5.3$ (with goniatite Timanites), A = approximately 5.7, B = 5.9, stylioline limestone with abundant Timanites, $\mathrm{D}=8.8$, top of brachiopod bed; top of hill =10.2. Collected by R.S. Nicoll and GK, 1988; W.T. Kirchgasser and GK, 1990.

West McPhee Knoll (WMcP, section 365), about $1.2 \mathrm{~km}$ WSW of the knoll, Old Bohemia Valley, description in Klapper (2007a, p. 537; 2009, p. 410), location shown in Becker \& House (1997, fig. 2, 365 indicated NW of Teichert Hills). Base of section is at AMG Zone $52,{ }_{1} 93800 \mathrm{E}_{79} 36500 \mathrm{~N}$. Bed numbers and stratigraphic position are given in meters above base of section from which specimens illustrated in figs 1, 3 were derived. Bed designations are all preceded by section number 365: Gogo Formation: 4=23.9-23.95. Virgin Hills Formation: $9=41.70-41.75,11=55.1-55.2,15=65.25-65.3$. Measured and collected by R.S. Nicoll, GK, and R.W. Brown, 1988. 